\title{
LOS EMPERADORES TAUMATURGOS: CURACIONES PRODIGIOSAS DESDE Trajano a Napoleón*
}

\author{
Víctor Mínguez Cornelles \\ Universitat Jaume I
}

RESUMEN: Existió una ceremonia que desde los tiempos primitivos hasta el siglo XIX aproximó físicamente a las clases marginales, especialmente a sus miembros enfermos, al restringido círculo de poder que representa en todas las épocas la realeza: la curación taumatúrgica. En la Roma imperial, en la Edad Media cristiana, en las cortes modernas de Francia e Inglaterra y en la Europa napoleónica podemos rastrear testimonios gráficos y documentales de un ritual mágico o sagrado mediante el cual un príncipe determinado sana a sus súbditos. ¿Se manifestó este poder en la corte española? Pues más de lo que puede parecer a primera vista, si tenemos en cuenta los posibles milagros de los reyes santos, la política ilustrada metaforizada en reyes cirujanos o determinadas sanaciones atribuidas a cadáveres regios. Incluso alguna pintura cortesana como por ejemplo La recuperación de Bahía de Todos los Santos, de Juan Bautista Maíno, puede interpretarse desde esta perspectiva. La taumaturgia se convirtió allí donde surgió en manifestación de la realeza. Y cuando Napoleón hace ostentación de su poder curativo en la pintura de Gros, Bonaparte... en el hospital de Jaffa, no busca otra cosa que legitimar su autoridad al asumir un ritual propio de la monarquía divina.

Palabras clave: poder, taumaturgia, realeza, Felipe IV, Napoleón.

ABSTRACT: From primitive times to the nineteenth century, a ceremony existed that brought the marginalised classes, particularly the sick,

* Esta investigación ha sido realizada en el marco del Proyecto de Investigación HAR2009-08937, financiado por el Ministerio de Ciencia e Innovación. Fue presentada como ponencia al XVIII Congreso Nacional de Historia del Arte (Universidad de Santiago de Compostela, septiembre, 2010), y publicada en las actas del congreso en formato digital (2012). He considerado oportuno editarla ahora en formato papel tras introducir pequeñas modificaciones debidas a nuevos datos y nuevas imágenes halladas. 
physically closer to the restricted circle of power represented by royalty in all periods: thaumaturgic healing. In Imperial Rome, the Christian Middle Ages, the modern French and English courts and in Napoleonic Europe we can trace graphic and documentary testimonials of a magic or sacred ritual in which a certain prince would heal his subjects. Was this power evidenced in the Spanish court? Indeed, more than what first impressions might suggest if we take into account the possible miracles of the holy monarchs, enlightened politics metaphorised in surgeon kings or certain healings attributed to royal corpses. Some royal court paintings such as The Recapture of Bahia, by Juan Bautista Maíno, may even be interpreted from this perspective. Wherever it occurred, thaumaturgy became a manifestation of royalty. And when Napoleon boastfully displays his healing powers in Gros's painting, Bonaparte Visiting the Plague-Stricken in Jaffa, he is clearly seeking to legitimise his authority by performing a ritual associated with the divine monarchy.

Keywords: Power, thaumaturgy, royalty, Philip IV, Napoleon.

\section{INTRODUCCIÓN}

$\mathrm{L}^{2}$ a identificación entre el rey y Dios, entre realeza y religión, desde la Roma antigua hasta -de distintas maneras- la era de las revoluciones, dotó a determinados monarcas europeos de propiedades sanadoras, bien mágicas como en el caso de las cortes francesa e inglesa- bien milagrosas o simbólicas -como en el caso de la corte española. La capacidad taumatúrgica de los monarcas fue quizá la vía principal por la que los reyes se aproximaron en todos los tiempos a sus súbditos más desfavorecidos: enfermos, marginados y desheredados encontraron el consuelo a sus males mediante imágenes o ritos pretendidamente curativos. Hasta el siglo XVII los reyes santos son los principales sujetos de admiración y respeto, por su singular capacidad milagrera. En el siglo XVIII los príncipes ilustrados ya no se limitan a resolver desgracias particulares, sino que pretenden curar los males colectivos del pueblo por medio de la acción política. En todas las épocas, la aproximación y el contacto directo con el rey -el toque- se percibe como la más eficaz terapia para los miembros más desposeídos de la sociedad. Incluso la guillotina revolucionaria -inventada por un médico- pretende amputar los miembros enfermos de la nación, y hasta el propio Napoleón I recuperará en su iconografía el poder del «toque real».

Hubo una pintura en la corte española de Felipe IV (actualmente en el Museo del Prado) cuya iconografía ha sido analizada profusamente, pero de 
la que nunca se ha destacado su importancia como representación del poder taumatúrgico de la realeza. Me refiero al lienzo de Juan Bautista Maíno, La recuperación de Bahía de Todos los Santos, pintado hacia 1634-1635, como uno más de los doce lienzos de batalla encargados a distintos pintores que debían decorar el Salón de Reinos del Palacio del Buen Retiro. La exposición de un herido en primer plano y la aparición salvífica del monarca no pueden interpretarse simplemente como una evocación del socorro militar que liberó a la ciudad de Bahía de la invasión holandesa, sino también como una sutil referencia al poder taumatúrgico de la monarquía hispana que, como luego veremos, aunque no tan manifiesto como en los casos de la corona inglesa y la francesa, sí estuvo presente en determinados momentos en la cultura y en la política española, como no podía ser de otro modo, pues dicha construcción simbólica se remonta al modelo imperial romano y a la tradición cristiana medieval, y había dejado su huella en todas las civilizaciones desde el origen de los tiempos.

Poder, magia y medicina son conceptos asociados en las culturas más primitivas, como explicó con gran sabiduría James George Frazer en su excelente estudio de antropología cultural, La rama dorada (1922). El capítulo de su obra denominado «Los reyes magos» ofrece un repaso por culturas primitivas australianas, melanesias, malayas, africanas y americanas, demostrando que la magia fue la antecesora del poder político, y que magos, hechiceros, chamanes y curanderos transmutaron en reyes con el tiempo. ${ }^{1}$ El poder curativo por medio de determinadas palabras, la imposición de las manos o de los pies, o simplemente su presencia, era una de las capacidades de estos predecesores de la realeza sacra.

Los milagros y prodigios presentaron a los reyes ante sus súbditos como una realeza sagrada, empleando la definición de Jean Hani -«que se reconoce que ejerce un mandato del cielo confirmado por medio de un acto de la autoridad espiritual y de los ritos apropiados»-, ${ }^{2}$ investida de poderes mágicos de los que carecen los demás mortales. Dicho poder taumatúrgico legitimaba a los monarcas pues evidenciaba ante los humanos su carácter sagrado. Y sucede tanto si nos encontramos ante «realezas divinas», «realezas por gracia divina» o «reyes sacerdote». Desde los emperadores sumos sacerdotes romanos a los reyes absolutos de época moderna elegidos por el dios cristiano, pasando por los emperadores ungidos y nimbados bizantinos o por los reyes canonizados o representados como santos, la manifestación de poderes sobrenaturales pone de relieve el estrecho nexo entre la divinidad y el monarca. Evidentemente no es el único elemento a tener en cuenta en este sentido: así por ejemplo, el ceremonial cortesano, reflejo del antiguo culto a los césares de Roma, es otro

1. J. G. Frazer: The Golden Bough, The Macmillan Company, Nueva York, 1992. Se cita la edición castellana: La rama dorada, Fondo de Cultura Económica, España, 1981, pp. 113-121.

2. Jean Hani: La realeza sagrada. Del faraón al cristianísimo rey, José J. de Olañeta, Palma de Mallorca, 1998, p. 16 
aspecto esencial de la realeza sagrada. Pero el toque curativo, esporádico y limitado, ha sido a lo largo de la historia la prueba más evidente del componente divino de la realeza.

\section{Vespasiano y el Poder taumatúrgico}

No hay apenas referencias a los poderes taumatúrgicos de los emperadores romanos en las fuentes clásicas. Pero hay dos, por lo menos, de gran interés: los relatos de Tácito y Suetonio sobre la supuesta capacidad sanadora del emperador Vespasiano, ejercida en Oriente. Recojo a continuación ambas narraciones:

Tácito, Historias (escrito a finales del siglo I, principios del siglo II d. C.).

81. Vespasiano y Oriente. Prodigios. Durante aquellos meses en los que Vespasiano esperaba en Alejandría los días fijos para los vientos estivales y la seguridad del mar, ocurrieron muchos portentos, con los que se manifestaba el favor de los cielos y una cierta inclinación de las divinidades hacia Vespasiano. Uno de la población de Alejandría, conocido por una consunción de sus ojos, se postra ante sus rodillas pidiendo entre gemidos el remedio de su ceguera, por indicación del Dios Serapis, a quien su pueblo, entregado a las supersticiones, da culto por encima de los demás, y suplicaba al emperador que se dignase rociar sus mejillas y las órbitas de sus ojos con la secreción de su boca. Otro, impedido de una mano, pedía, con el mismo dios por instigador, que fuera hollada con el pie y la pisada de César.

Vespasiano, al principio, se burlaba, no les hacía caso. Y al insistir ellos, por un lado temía una fama de vanidad, por otro lado se sentía inducido a la esperanza por los ruegos de aquellos y por las palabras de los que lo adulaban. Al fin, ordena que se dictamine por los médicos si tal ceguera y parálisis eran superables por medios humanos.

Los médicos respondieron con diversas consideraciones: «al uno no se le había extinguido la potencia visual y le volvería, si se eliminaban los obstáculos; al otro, los miembros, que se la habían dislocado, podían ponérsele en su sitio, si se ejercía una presión reparadora: esto era quizá del agrado de los dioses y el emperador había sido elegido para el divino misterio; en fin, la gloria de la eficacia del remedio quedaría en manos de César; el bochorno del fracaso, en las de los desdichados».

Con que Vespasiano, pensando que todo estaba al alcance de su fortuna y que nada en adelante sería increíble, incluso con el rostro alegre, en tensión la muchedumbre que permanecía sin moverse, pone en práctica lo que se le había prescrito. Al momento, la mano volvió a su función y para el ciego volvió a brillar el día.

Ambos prodigios los recuerdan todavía ahora los testigos presenciales, cuando ya no hay premio ninguno para la mentira. 


\section{Cayo Suetonio Tranquilo Los Doce Césares (escrito en el siglo II d. C.)}

VII. Se decidió, pues, Vespasiano, a empezar la guerra civil, y habiendo enviado sus legados a Italia con tropas, marchó él a Alejandría a fin de apoderarse de las fronteras del Egipto. Quiso allí consultar los oráculos sobre la duración de su reinado, y entró solo en el campo de Serapis, haciendo salir antes a todos. Después de hacerse propicio el dios volvióse y creyó ver al liberto Basílides que le presentaba, según la costumbre del templo, tallos de verbena, coronas y pastelillos. Nadie, sin embargo, había introducido a Basílides, a quien una enfermedad nerviosa impedía andar hacía ya mucho tiempo, y a quien sabían todos muy lejos de allí. Recibió luego cartas anunciándole que las tropas de Vitelio habían sido vencidas en Cremona y este príncipe muerto en Roma. Una circunstancia particular vino a imprimir a la persona de Vespasiano el sello de grandeza y majestad que faltaba a este príncipe, nuevo aún, y en cierta manera improvisado. En efecto, dos hombres del pueblo, ciego el uno y cojo el otro, se presentaron juntos ante su tribunal, suplicándole los curase, pues decían que, estando dormidos, les había asegurado Serapis, al uno que recobraría la vista si el emperador le escupía en los ojos; al otro que caminaría recto si se dignaba tocarle con el pie. No podía creer en el éxito de aquel remedio, y ni siquiera se atrevía a intentarlo, pero al fin, vencido Vespasiano por las instancias de sus amigos, probó a hacer lo que le pedían delante de la asamblea, y los dos hombres fueron sanados. Por el mismo tiempo ordenaron los adivinos hacer excavaciones en Tegeo, en Arcadia, encontrándose enterrados en paraje sagrado vasos antiguos en los que estaba grabada una figura que se parecía a Vespasiano.

El poder taumatúrgico que Vespasiano ejerció una vez llegó a Oriente sanando a un ciego, a un cojo o manco, ajeno hasta ese momento a la tradición latina de los césares romanos, es ante todo un ejercicio propagandístico de la práctica del poder. Si hacemos caso a Tácito y Suetonio, ni siquiera Vespasiano creía en su poder curativo, pero según Tácito el emperador se asesoró de médicos que le confirmaron que por razones naturales ambas curaciones eran posibles, y es entonces cuando Vespasiano decide arriesgarse para aumentar su prestigio, «pensando que todo estaba al alcance de su fortuna y que nada en adelante sería increíble». Vespasiano, un emperador honesto, pragmático y nada orientalista ni helenista convierte una pretendida curación en un acto de propaganda al servicio del poder.

Según Miguel Requena estos relatos de milagros y otras muchas historias maravillosas protagonizadas por los emperadores y narradas por los historiadores de la Antigüedad tienen significación histórica, pues son un reflejo de su época y elementos fundamentales para conocer adecuadamente la concepción sociológica del poder imperial. ${ }^{3}$ Una concepción del poder que se trasladará a la iconografía. Lo podemos comprobar en un denario de plata

3. Miguel Requena: Lo maravilloso y el poder. Los presagios del imperio de los emperadores Aureliano y Tácito en la Historia Augusta, Universitat de València, Valencia, 2003, p. 87. 
acuñado en Roma (72-73 d. C.), que muestra en su anverso el busto del emperador Vespasiano mirando hacia la derecha y en el reverso diversos objetos usados en sacrificios (báculo, copa, jarra...), que aluden al rol curativo del emperador [Fig. 1].

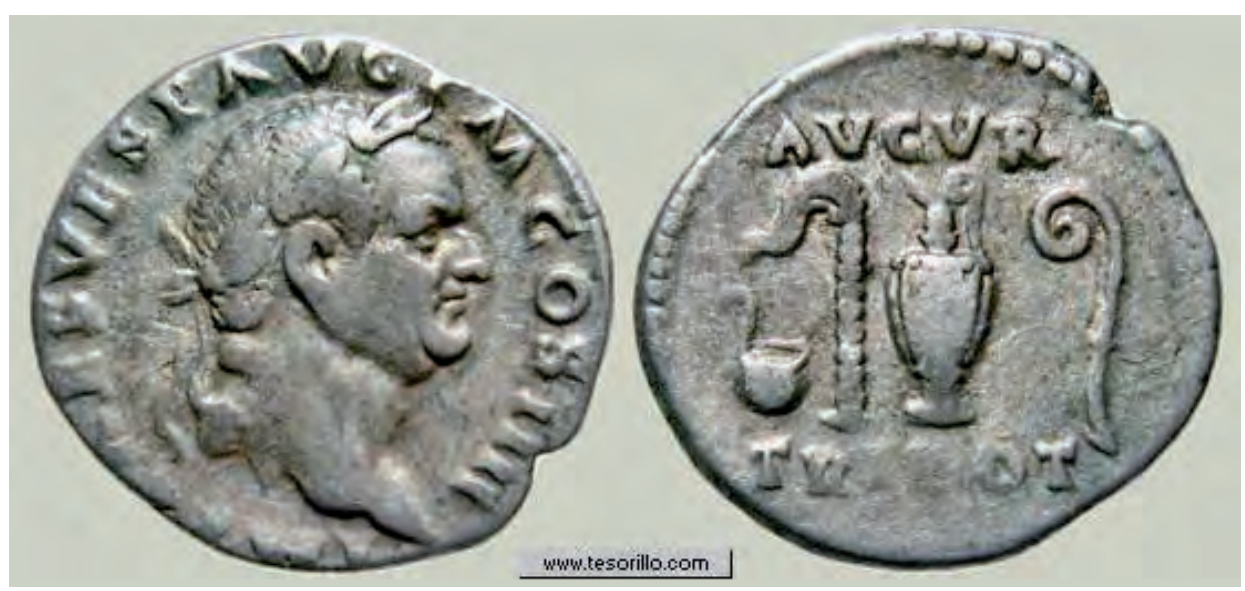

Fig. 1. Vespasiano, denario de plata romano (72-73 d. C.)

\section{LA EDAD MEDIA, LOS MILAgROS Y LA REALEZA TAUMATÚRGICA}

La llegada del cristianismo no implicó la desaparición de la taumaturgia regia, más bien la potenció. Al fin y al cabo se adoraba a un Dios que durante su paso por la tierra realizó múltiples curaciones, individuales y masivas, recogidas en los Evangelios, como prueba y manifestación de su poder divino. ${ }^{4}$ Según Marc Bloch toda la realeza europea durante el Medievo y la Edad Moderna fue maravillosa y sagrada, aunque solo en Francia e Inglaterra encontramos reyes médicos. ${ }^{5}$

Sin embargo, si consideramos la curación de las escrófulas -inflamaciones de los ganglios linfáticos ocasionadas por los bacilos de la tuberculosis-, de la epilepsia o de otras dolencias por parte de los reyes, el fruto de un milagro, hay que convenir que los reyes santos canonizados por la Iglesia y por lo tanto, poseedores de una naturaleza capaz de hacer milagros, pudieron poseer un

4. Véase E. DAl Covolo, I. Giannetto (curr.): Cultura e promozione umana. La cura del corpo e dello spirito. Fundamenti e itinerari, Oasi Editrice, Troina, 1996; E. DAl Covolo, I. Giannetto (curr.): Cultura e promozione umana. La cura del corpo e dello spirito nell'antichità classica e nei primi secoli cristiani. Un magisterio ancora attuale?, Oasi Editrice, Troina, 1998. E. Dal Covolo, I. Giannetto (curr.): Cultura e promozione umana. La cura del corpo e dello spirito dai primi secoli cristiani al Medioevo: contributi e attualizzazioni ulteriori, Oasi Editrice, Troina, 2001. W. J. SHEILs: The Church and Healing, The Ecclesiastical History Society, Oxford, 1982.

5. MARC Bloch: Les rois thaumaturges, Estrasburgo, 1924. Se cita la edición castellana de 1988, Los reyes taumaturgos, impresa en México por el Fondo de Cultura Económica, p. 28. 
poder similar al de los reyes taumaturgos franceses e ingleses, incluso aunque no lo ejercieran. Tendríamos, por consiguiente, reyes taumaturgos y reyes santos con capacidad taumatúrgica, demostrada o no. E incluso algún rey santo y taumaturgo: es el caso de San Luis de Francia, canonizado por la Iglesia y a la vez rey curador por pertenecer a la casa real francesa.

Reyes santos hubo en diversos reinos medievales europeos, por lo tanto, los prodigios no necesariamente estuvieron reservados a Francia e Inglaterra. Sí que es cierto, sin embargo, que en estos dos países existió todo un ritual centrado en el carácter taumatúrgico de sus monarcas, cosa que no sucedió en otras cortes europeas. En ambos reinos las escrófulas, enfermedad no mortal pero repulsiva, eran denominadas el mal del rey. Desde el siglo XII -Felipe I Capeto y Enrique II Plantagenet fueron los primeros de los que se tiene noticia- los monarcas franceses e ingleses las curaban mediante el contacto de sus manos: de manera regular una multitud acudía para ello ante la presencia real, y el rey tocaba las escrófulas una por una y hacía cada vez la señal de la cruz. Se trataba de un poder divino y hereditario. Como cuenta Marc Bloch, los médicos de ambos países aceptaban de buena gana el poder curativo del monarca, en tanto se trataba de un milagro, mientras que los eclesiásticos se dividieron al respecto -eran contrarios, por ejemplo, los partidarios de la supremacía papal. ${ }^{6}$ Además de este poder, los reyes ingleses detentaron una segunda capacidad: desde Eduardo II Plantagenet los monarcas bendecían el día del Viernes Santo anillos medicinales, especialmente indicados para curar los espasmos musculares y la epilepsia. Por esta razón fueron llamados cramprings, o anillos contra el calambre.

Nos han llegado diversos testimonios visuales del poder curativo de los reyes de Francia. Es el caso de la imagen «Eduardo el confesor toca las escrófulas de una mujer», en el manuscrito La Estoire de Seint Aedward le Rei (Biblioteca de la Universidad de Cambridge), o del también manuscrito Grandes Chroniques de France (Bretagne, folio 248, 1450?-1475?), en el que en una misma hoja vemos dos miniaturas: «Luis IX con los pobres», y «Luis IX tocando las escrófulas». Las imágenes taumatúrgicas de la realeza francesa continúan durante el Renacimiento y la Edad Moderna. Veamos como ejemplo el Libro de Horas de Enrique II (Heures de Enri II) (Bibliothèque Nationale, París, folio 107v, 1547-1550), iluminado por el Maître des Epîtres Getty, que muestra una de las representaciones plásticas más conocidas del poder taumatúrgico: en ella contemplamos al rey Enrique II tocando las escrófulas en la abadía de Saint-Marcoul de Cobény [Fig. 2]. La curación regia en este momento formaba parte ya del ritual de la coronación-consagración de los reyes de Francia en la ciudad de Reims. ${ }^{8}$

6. BLOCH, Les rois thaumaturges, pp. 114-141.

7. Ibidem, pp. 152-174.

8. Ralph E. GIESEY: «Models of Rulership in French Royal Ceremonial», cap. IX de su libro Rulership in France, $15^{\text {th }}-17^{\text {th }}$ Centuries, Ashagate Variorum, 2004, pp. 43-46. 


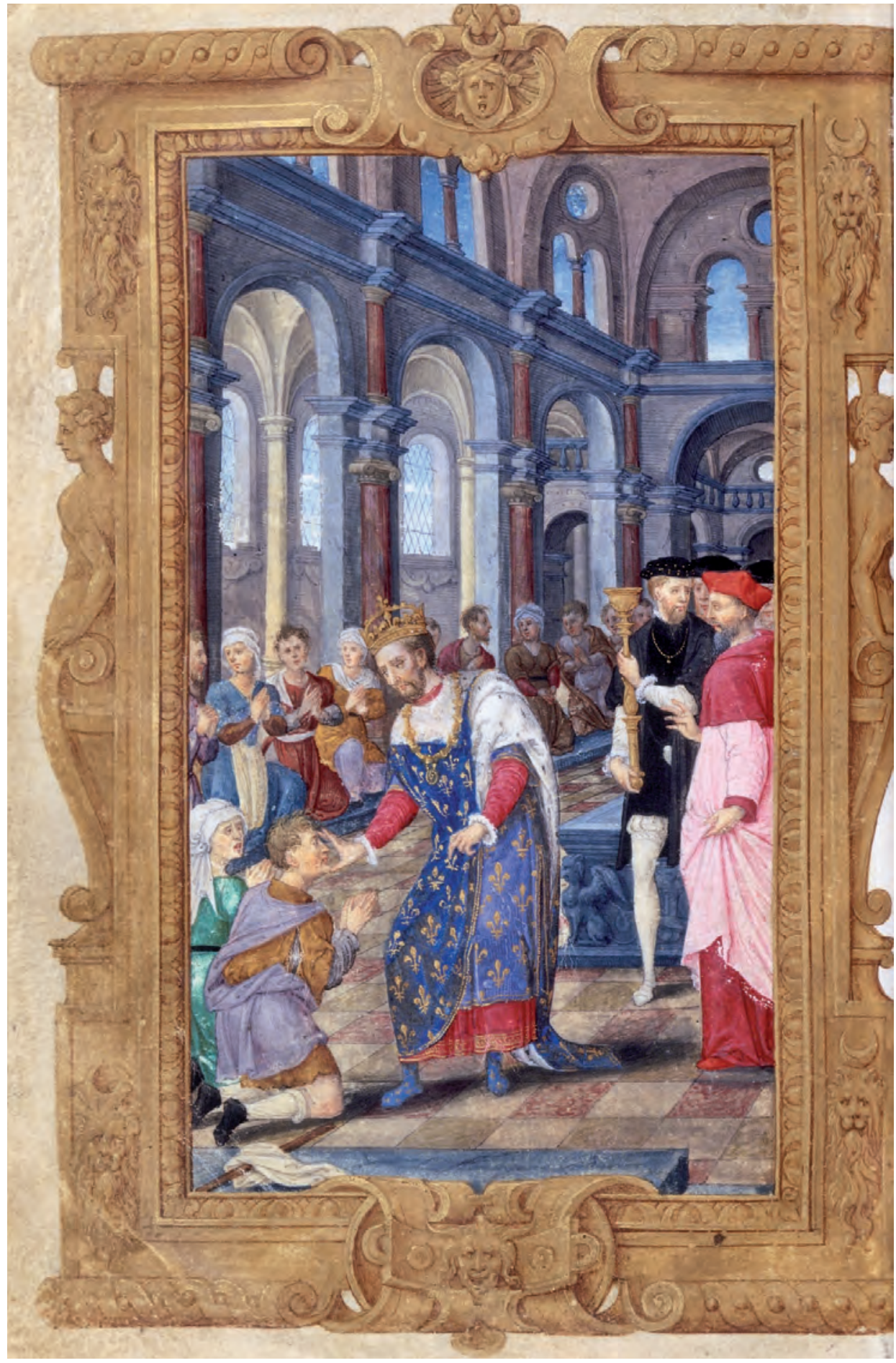

Fig. 2. Maître des Epîtres Getty, Libro de Horas de Enrique II (Heures de Enri II) (Bibliothèque Nationale, París, folio 107v, 1547-1550) 


\section{LOS REYES SANTOS Y LOS SANTOS REYES}

Durante la Edad Moderna, reyes católicos y príncipes protestantes detentan el poder absoluto, y sus representaciones iconográficas traspasan todos los límites a la hora de emparentarse o identificarse con la divinidad. Así por ejemplo, Tiziano pintará a la familia imperial hispana visitando a la Trinidad en el cielo en el lienzo La Gloria (Museo del Prado) y Pierre Paul Sevin pintará en una vitela a Luis XIV como el Buen Pastor. Sin llegar a estos excesos, lo cierto es que las casas reales europeas, desde la Baja Edad Media, gustaron de dotarse en su imagen genealógica de algún rey santo que aumentara su prestigio. Esta estrategia fue especialmente intensa en el caso de Francia y España, cuyos reyes fueron proclamados respectivamente por el Papado cristianísimos y católicos. Subyacía en el fondo una feroz competencia por ser reconocidos unos y otros como paladines de la cristiandad, competencia que se reflejaría por ejemplo en el Concilio de Trento, cuando los embajadores de uno y otro reino disputaron su precedencia. Entonces el argumento utilizado por el embajador francés para defender su derecho fue la circunstancia de que la Casa de Francia contaba ya con un santo reconocido por la Santa Sede, San Luis. ${ }^{9}$ Pero Francia no era el único reino que exhibía reyes santos. Otros hacían lo propio, como Hungría o Portugal.

San Luis IX de Francia (1214-1270) destacó por su caridad y su impulso en la construcción de iglesias, y participó en las cruzadas. Según sus hagiógrafos, su tumba en la abadía de Saint-Denis fue fuente de milagros. Estos fueron clasificados y documentados para impulsar su canonización, proceso iniciado por su esposa Margarita de Provenza. Bonifacio VIII lo canonizará en 1297. ${ }^{10}$ Algunos ejemplos artísticos de su presencia al lado de los enfermos son los lienzos de Louis Testelin, Saint Louis soignant les malades atteints de la peste (1654-55, Museo de Grenoble) [Fig. 3] y de Louis Licherie de Beurie, Saint Louis soignant ses soldats atteints de la peste (entre 1678 y 1681, Museo de Bellas Artes de Rouen). Santa Isabel de Hungría (1207-1231), hija del rey Andrés II el Hierosolimitano, y casada con el landgrave Luis de TuringiaHesse, al enviudar destinó sus riquezas a fundar diversos hospitales y a repartir limosna entre los pobres. Muerta en Marburgo a los 24 años de edad, el papa Gregorio IX la canonizó muy poco después, en 1325. La representación plástica más conocida de esta princesa caritativa fue realizada por Bartolomé Esteban Murillo, Santa Isabel de Hungría curando a los tiñosos (1667-1670, Hospital de la Caridad, Sevilla) [Fig. 4]. También el reino de Portugal contó tempranamente con una reina santa, Santa Isabel, nieta de Jaime I de Aragón

9. Antonio Álvarez-Ossorio Alvariño, estudio introductorio para la obra de Baltasar Porreño: Dichos y hechos del Señor Rey Don Felipe Segundo, el Prudente, Potentísimo, y Glorioso Monarca de las Españas, y de las Indias, Sociedad Estatal para la Conmemoración de los Centenarios de Felipe II y Carlos V, Madrid, 2001, pp. IX-CXxvi; Inmaculada Rodríguez: «Los reyes santos», en Víctor Mínguez (ed.): Visiones de la monarquía hispánica, Universitat Jaume I, Castellón, 2007, pp. 133-169.

10. Henry Bordeaux: San Luis, rey de Francia, Espasa Calpe Argentina, Buenos Aires, 1951. 
y esposa de Dionisio I, rey de Portugal. Fallecida en 1336, su cadáver enterrado en el convento de Santa Clara de Coimbra recibió tempranamente culto y provocó supuestos milagros, entre ellos curaciones. El rey Manuel promovió el proceso de canonización, siendo beatificada en 1516 por León X, y canonizada en 1625 por Urbano VIII, en el tiempo en que el reino de Portugal formaba parte del Imperio español. Entre las representaciones curativas de esta reina destaca el lienzo pintado también por Murillo, Santa Isabel curando a los leprosos (Real Academia de Bellas Artes de San Fernando, Madrid). Más de un siglo después Francisco de Goya pintaría también a Santa Isabel de Portugal curando la llaga de una enferma [Fig. 5], lienzo que junto a otros dos centrados en San Fernando y en San Hermenegildo fueron pintados para la iglesia zaragozana de San Fernando de Torrero, en lo que configuró sin duda un programa iconográfico de reyes santos. Perdidas estas pinturas durante la guerra de Independencia se conserva el boceto del primer lienzo (1799, Museo de la Fundación Lázaro Galdiano). ${ }^{11}$

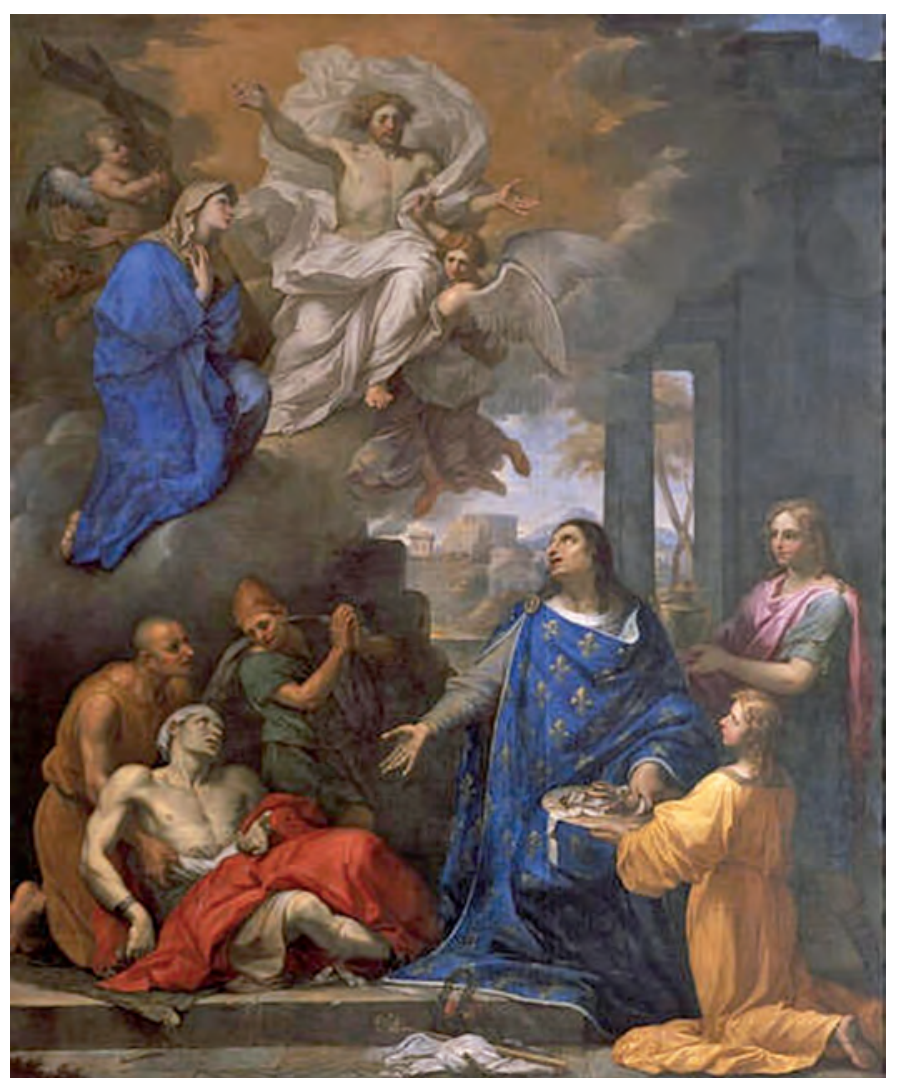

Fig. 3. Louis Testelin, Saint Louis soignant les malades atteints de la peste (1654-55, Museo de Grenoble)

11. Ignacio J. Calvo: Imagen de la Reina Santa. Santa Isabel, infanta de Aragón y reina de Portugal, Diputación de Zaragoza, Zaragoza, 1999. 


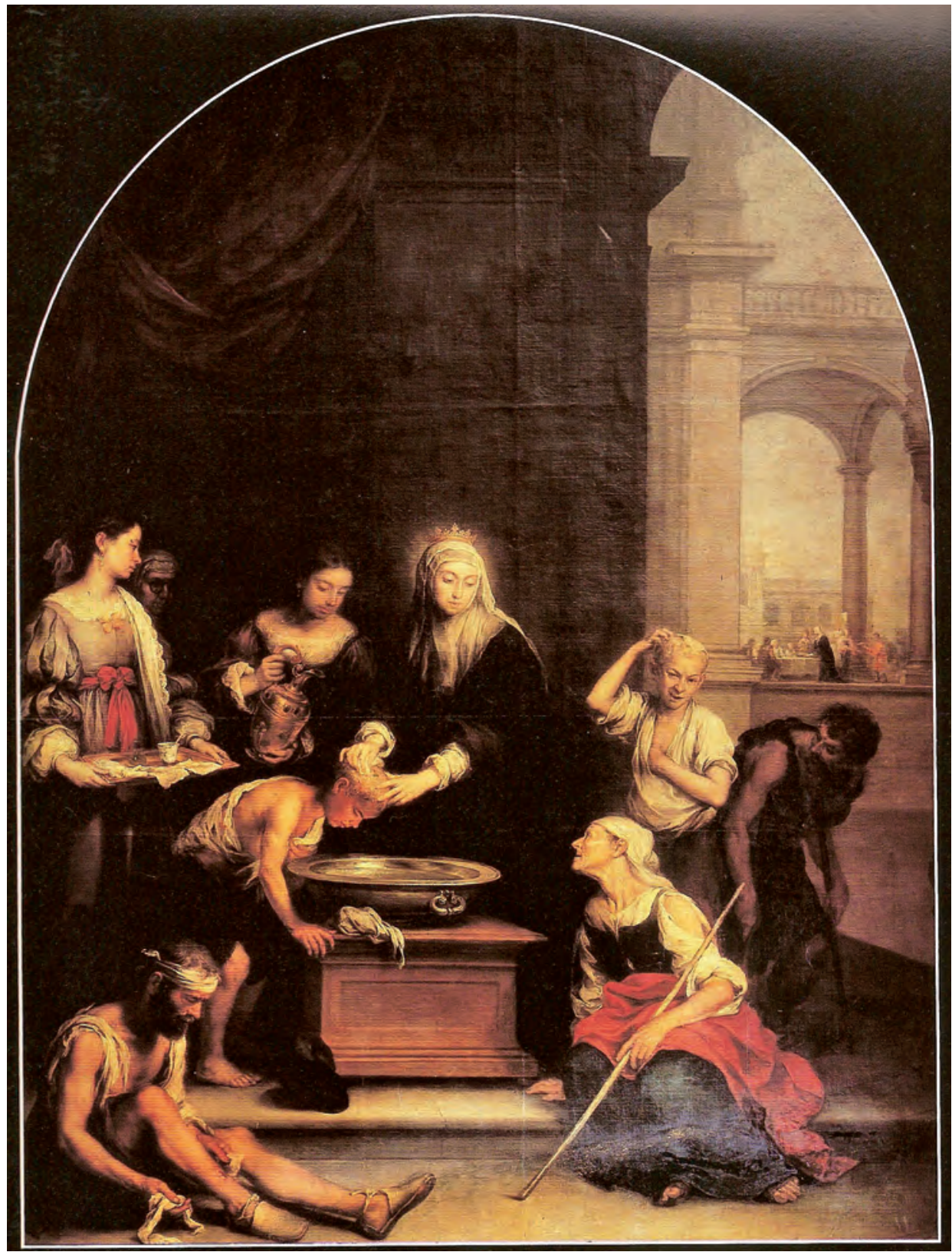

Fig. 4. Bartolomé Esteban Murillo, Santa Isabel de Hungría curando a los tiñosos (1667-1670, Hospital de la Caridad, Sevilla) 


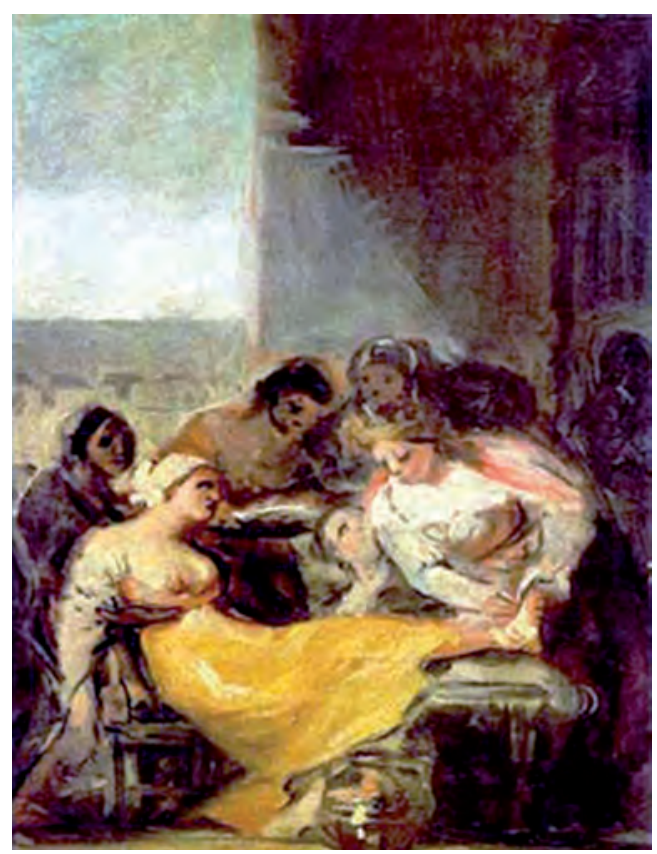

Fig. 5. Francisco de Goya, Santa Isabel de Portugal curando la llaga de una enferma (1799, Museo de la Fundación Lázaro Galdiano)

En el caso de la monarquía española el impulso para detentar la preferencia entre los reinos cristianos era constante: Fernando de Aragón e Isabel de Castilla recibieron el título de Reyes Católicos de manos del papa Alejandro VI en 1496, y su nieto Carlos V fue coronado emperador del Sacro Imperio en 1530. Solo le faltaba a la dinastía contar con un rey santo. Durante la primera mitad del siglo XVII los esfuerzos diplomáticos y propagandísticos en este sentido fueron constantes, y se barajaron varios nombres: don Pelayo, Hermenegildo, Alfonso VIII, Fernando III, Jaime I o incluso los propios Reyes Católicos. A la hora de decidirse por uno determinado se valoró una vida virtuosa, un culto inmemorial, y lo más relevante, milagros documentados. Cumplían pretendidamente estas condiciones Hermenegildo y Fernando III, pero el primero nunca fue rey, solo príncipe, y además se rebeló contra su padre, así que finalmente el elegido fue Fernando III.

Fernando III, rey de Castilla y León (1217/1230-1252), ${ }^{12}$ conquistador de gran parte de Andalucía -Córdoba, Jaén y Sevilla- y Murcia, y primo hermano de San Luis de Francia, recibía culto por tradición en Sevilla, aunque no reconocido por Roma. Su cuerpo incorrupto y su espada se conservaban en la Capilla Real de la catedral sevillana. Detrás de su candidatura, además de los intereses ya explicados de la monarquía hispánica, se situaron las elites eclesiástica, municipal y comercial de Sevilla, y por supuesto el valido conde-

12. Gonzalo Martínez Díez: Fernando III, 1217-1252, Diputación de Palencia, Palencia, 1993. 


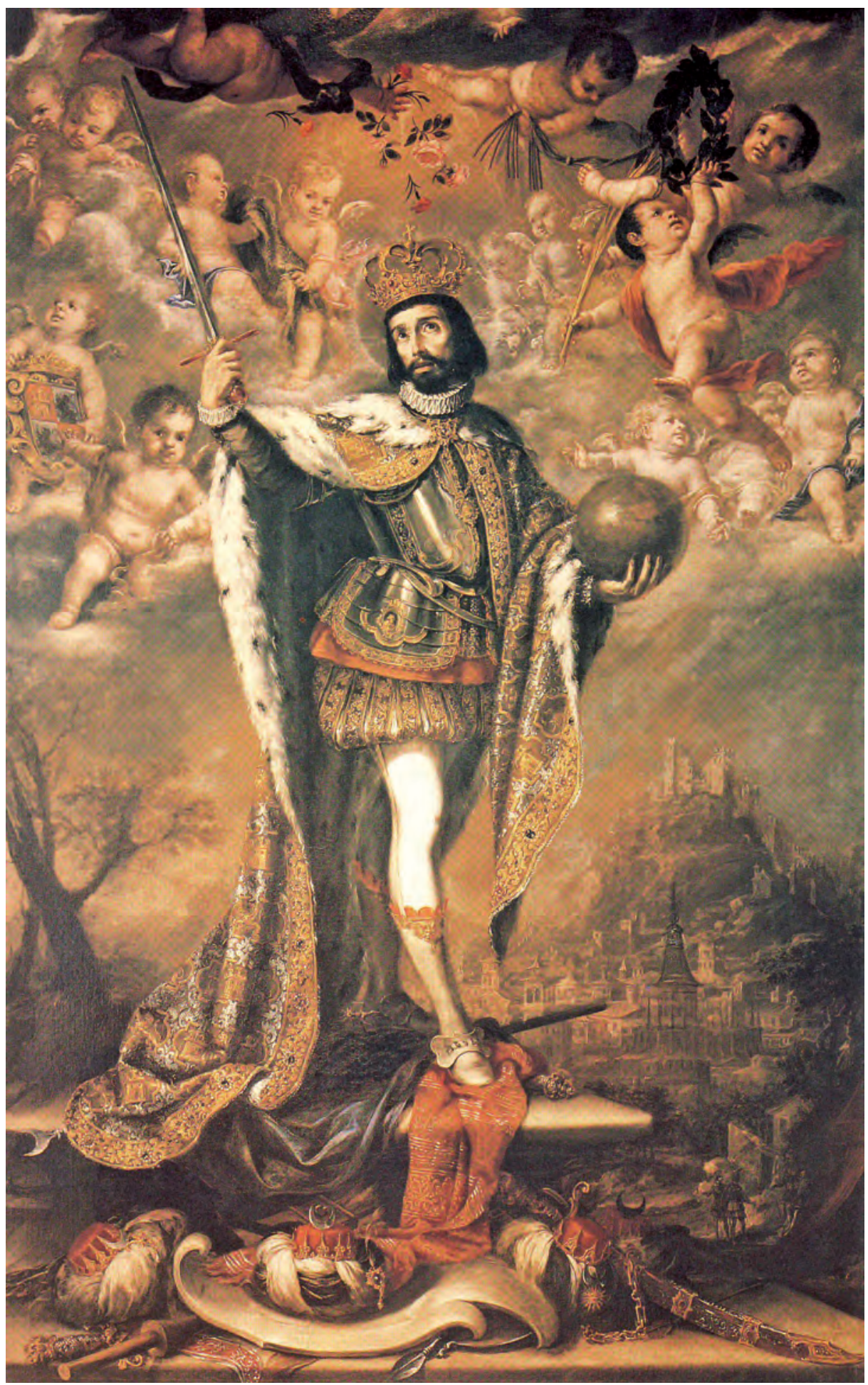

Fig. 6. Valdés Leal, San Fernando, Catedral de Jaén 
duque de Olivares, natural de esta ciudad. Todos unidos con el claro objetivo de promover el prestigio de la urbe y de la realeza hispana. El memorial presentado en Roma incluía el catálogo de sus milagros. ${ }^{13}$ Entre las imágenes del rey santo fabricadas en este momento destaca la estampa realizada en Roma por Claude Audrán, Fernando III el Santo (Biblioteca Nacional, Madrid, 1630), probablemente la que tuvo mayor trascendencia a la hora de difundir su iconografía, encargada por el embajador español en la Santa Sede Bernardo del Toro para ayudar a promover su canonización. ${ }^{14}$ En ella contemplamos al monarca de cuerpo entero con armadura y manto. Sostiene con una mano la espada, con la otra el globo y la corona en la cabeza aureolada. El cetro, la columna, el escudo heráldico y un cielo abierto son los otros elementos simbólicos. La imagen fue copiada muchas veces, y el propio embajador encargó cinco lienzos y doce láminas reproduciéndola..$^{15}$ En 1671 el papa Clemente X reconocía el nuevo culto del rey San Fernando. Dos años después Valdés Leal pintaba el magnífico retrato de San Fernando para la catedral de Jaén, con una iconografía similar a la ya vista, si bien la composición resultó mucho más espectacular [Fig. 6].

Como vemos, la capacidad milagrera de los reyes -o de sus cadáveres sepultados- era un elemento esencial para ser reconocidos como santos, y entre estos milagros destacaban obviamente las pretendidas curaciones. Por lo tanto, y en el seno del catolicismo, a través de las canonizaciones de reyes cristianos, se reforzó la imagen taumatúrgica de la realeza europea. Y la identificación entre realeza y santidad no acababa con la canonización de pretendidos reyes santos del pasado remoto. Los reyes hispanos -y especialmente los integrantes de la Casa de Austria- gustaron de retratarse en diversas ocasiones con la iconografía de personajes del santoral cristiano. Es el caso del retrato de Catalina de Aragón como Santa Catalina, pintado por Michel Sittow (1504-1505, Kunsthistorisches Museum, Viena). O de los lienzos anónimos de Maximiliano II como San Valerio de Tréveris y Rodolfo II como San Víctor (Patrimonio Nacional, Madrid, Monasterio de las Descalzas Reales), dos retratos de aparato camuflados como representaciones hagiográficas que seleccionan a dos santos cuyos cuerpos completos se conservaban en el relicario del monasterio madrileño de las Descalzas Reales, residencia para la que fueron

\footnotetext{
13. RODRíGUEZ, «Los reyes santos», p. 151.

14. Ibidem, p. 152.

15. Sobre la iconografía de Fernando III el Santo, además del estudio de Inmaculada Rodríguez ya citado, véanse Fernando Moreno Cuadro: Iconografía de San Fernando en Córdoba, Museo Diocesano de Bellas Artes, Córdoba, 1989; Adelaida Cintas del Bot: Iconografía de san Fernando en la pintura de Sevilla, Diputación de Sevilla, Sevilla, 1991; Ana Melero Casado y María Dolores Torres Pegalajar: «Fuentes documentales y bibliográficas para el estudio iconográfico de Fernando III», Archivo Hispalense, n. ${ }^{\circ} 7$, 1994, pp. 89-100; FERNANDo Quiles: «En los cimientos de la Iglesia sevillana: Fernando III, rey y santo», Boletín del Museo e Instituto «Camón Aznar», n. ${ }^{\circ}$ 75-76, 1999; Fernando Quiles García: Por los caminos de Roma. Hacia una configuración de la imagen sacra en el barroco sevillano, Miño y Dávila, Buenos Aires, 2005; y Alfredo J. Morales: «Rey y santo. Ceremonial por Fernando III en la catedral de Sevilla», en Víctor Mínguez (ed.), Visiones de la monarquía hispánica, Universitat Jaume I, Castellón, 2007, pp. 89-120.
} 


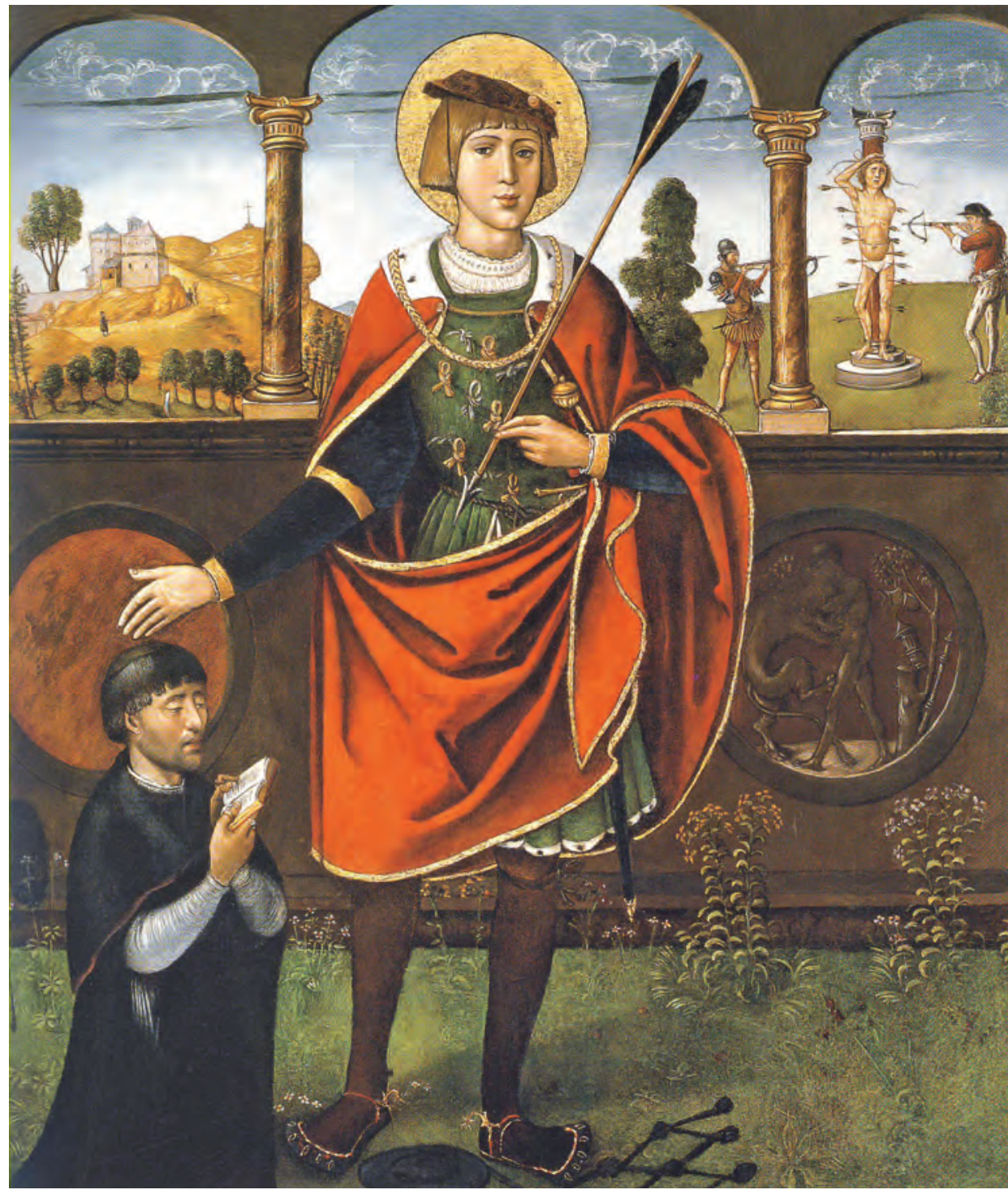

Fig. 7. Círculo de Juan de Borgoña, Carlos V como San Sebastián (1517-1527, Madrid, colección particular)

pintados. ${ }^{16} \mathrm{O}$ el óleo sobre tabla perteneciente al círculo de Juan de Borgoña, Carlos V como San Sebastián (1517-1527, Madrid, colección particular) [Fig. 7], en el que vemos a un emperador muy joven caracterizado como el santo en cuestión, representándose al fondo el martirio del santo, que se contrapone a

16. Ana García SAinz y Leticia Ruiz: «Linaje regio y monacal: la galería de retratos de las Descalzas Reales», en JAVier Portús (dir.), El linaje del Emperador, Sociedad Estatal para la conmemoración de los centenarios de Felipe II y Carlos V, 2000, pp. 150-151. 
la victoria de Hércules sobre el león de Nemea, mostrada en un medallón. Es decir, se comparan y se asemejan el poder del santo y el del monarca, revelado este último a través del referente mítico de la monarquía hispánica. ${ }^{17}$ Cito en último lugar un caso ya tardío pero muy singular, pues combina a un rey canonizado con la tradición de los retratos regios «a lo divino»: el pequeño óleo sobre cobre pintado por Jan van Kessel III, Carlos II como San Fernando, que hacía pareja con el de Mariana de Neoburgo como Santa Elena (ambos en colección particular). ${ }^{18}$ Es evidente que estas representaciones sacras otorgaban a los príncipes retratados, aunque fuera en un ámbito muy reducido, pues se trataba básicamente de pinturas privadas, las cualidades y virtudes de sus referentes, convirtiéndose por ello en posibles objetos de adoración y por lo tanto, capaces de interceder o de hacer milagros.

La fuerza visual que alcanzó en el arte cortesano la referencia a los reyes santos emparentados con la realeza hispana lo podemos comprobar a finales del siglo XVII. Cuando Luca Giordano llega a Madrid en 1692, el primer gran conjunto mural que va a realizar a la mayor gloria de la monarquía española será la bóveda de la escalera del Monasterio de El Escorial (1692-1694). En este gran fresco podemos contemplar a Carlos II mostrando a su madre Mariana de Austria y a su segunda esposa Mariana de Neoburgo un rompimiento de gloria que permite ver en el Cielo y junto a la Trinidad, a los dos primeros austrias hispanos, Carlos V y Felipe II, acompañados de diversos reyes santos: San Casimiro de Polonia, San Esteban de Hungría, San Enrique, emperador de Alemania; San Luis IX, rey de Francia; San Hermenegildo, y por supuesto, San Fernando III. ${ }^{19}$

\section{REYES ABSOLUTOS Y TAUMATURGOS EN INGLATERRA Y FRANCIA}

Medicina y poder real siguieron asociados en la corona francesa e inglesa durante la Edad Moderna.$^{20}$ Ya he hablado de las supuestas facultades curativas de los monarcas de Inglaterra y Francia. De cómo los reyes ingleses transmitían

17. Ángel Aterido: ficha catalográfica 3.2 del catálogo Javier Portús (dir.): El linaje del Emperador, Sociedad Estatal para la conmemoración de los centenarios de Felipe II y Carlos V, 2000, pp. 248-250.

18. José Luis SANCHO y Gloria Martínez Leiva: «¿Dónde está el rey? El ritmo estacional de la corte española y la decoración de los Sitios Reales (1650-1700)», en Fernando CheCa Cremades (dir.): Cortes del Barroco. De Bernini y Velázquez a Luca Giordano, SEACEx, 2003, p. 94.

19. Miguel Hermoso Cuesta: Lucas Jordán y la Corte de Madrid. Una década prodigiosa 1692-1702, Caja Inmaculada, 2008, pp. 90-91.

20. Sobre la taumaturgia real inglesa son interesantes los textos de Helen FARQuHAR, publicados en The British Numismatic Journal, y recogidos en el libro The King's Evil: Royal Charities. Part I. Angels as healing-pieces for the King's Evil, vol. XII, 1919, pp. 39-135; Royal Charities. Part II. Touchpieces for the King's Evil, vol. XIII, 1919, pp. 95-163; Royal Charities. Part III. Touchpieces for the King's Evil. James II to William III, vol. XIV, 1920, pp. 86-120, y Royal Charities. Part IV. Touchpieces for the King's Evil. Anne and the Stuart Princes, pp. 141-184. También son importantes las contribuciones de RAYMOND CRAwFURD: The King's Evil, Oxford, Clarendon Press, 1911, y P. S. LEwIS: «Two pieces of fifteenth political iconography», en Journal of the Warburg and Courtlaud Institutes, vol. XxVII, 1964, pp. 317-318. 
virtudes medicinales a anillos milagrosos. Y de cómo los reyes franceses por su parte -valois, capetos y borbones-, en días determinados se presentaban ante miles de sus súbditos enfermos de escrófulas y los curaban tocando las excrecencias con sus dedos.

El caso de Enrique IV de Francia resulta especialmente interesante. Como explica Joël Cornette, su conversión al catolicismo fue solo el primer paso para la reconciliación, simbólica y efectiva, entre él y su reino. Las siguientes etapas fueron la abjuración en Saint-Denis, la coronación en Chartres, la entrada en París y la absolución pontifical. Su entrada triunfal en París tiene lugar el martes 22 de marzo de 1594. Dieciocho días después, el domingo de Pascua, 10 de abril, tiene lugar la ceremonia que Cornette califica de consécration suprême, la ceremonia del toque de las escrófulas a cientos de enfermos. ${ }^{21} \mathrm{Un}$ grabado de Pierre Firens, Henri IV touchant les écrouelles (1609, Bibliothêque Nationale de France, Cabinet des estampes), muestra el rito: el monarca, en un espacio público lleno de cortesanos y soldados, se acerca uno por uno a la larga fila de enfermos arrodillados que esperan la curación e impone su mano sobre la cabeza de cada paciente sostenida por un médico. Evidentemente nos encontramos ante la representación de una ceremonia legitimadora de un rey que había sido cuestionado por su pueblo, y con el que ahora se reconciliaba sanando sus dolencias. Los Borbones heredaban de los Valois por lo tanto su poder taumatúrgico, un poder que devenía en supradinástico. El médico del rey, André du Laurens, publicará en 1609 un tratado sobre el poder curativo de los reyes de Francia concedido por Dios a los reyes cristianísimos. Cuando ochenta años después Jean Jouvenet pinte a Luis XIV curando la escrófula (Iglesia Abadía de Saint-Riquier, 1690) [Fig. 8], la imagen ya estará totalmente ritualizada: el rey Sol impone su mano sobre la cabeza del enfermo arrodillado, rodeado de numerosos testigos. Como en el grabado de Pierre Firens, los enfermos juntan las manos sobre el pecho en inconfundible gesto de devoción. Esta composición incorpora la figura de San Marcoul -reconocible por la aureola-, santo normando al que la creencia popular atribuía un papel intercesor en el poder taumatúrgico de los reyes de Francia, y cuyas reliquias se guardaban en Saint-Riquier. ${ }^{22}$

Los testimonios visuales que nos han llegado del rito inglés, no son muy distintos del modelo francés. Además, la ceremonia del toque real británico ha sido suficientemente estudiada. Anna Keay ofrece cifras concretas del número de enfermos tocados por Carlos II. ${ }^{23}$ Las imágenes más interesantes de las ceremonias taumatúrgicas de la corte inglesa pertenecen precisamente a este monarca. Un documento excepcional es The Manner of his Majesties

21. Jö̈l Cornette: Henri IV à Saint-Denis. De l'abjuration à la profanation, Belin, París, 2010, pp. 93-105.

22. Nicolas Milovanovic y Alexandre Maral (dirs.): Louis XIV. L'homme E Le roi, Skira Flammarion, París, 2009, p. 213.

23. AnnA KeAY: The magnificent monarch. Charles II and the Ceremonies of Power, Continuum, Londres-Nueva York, 2008. 


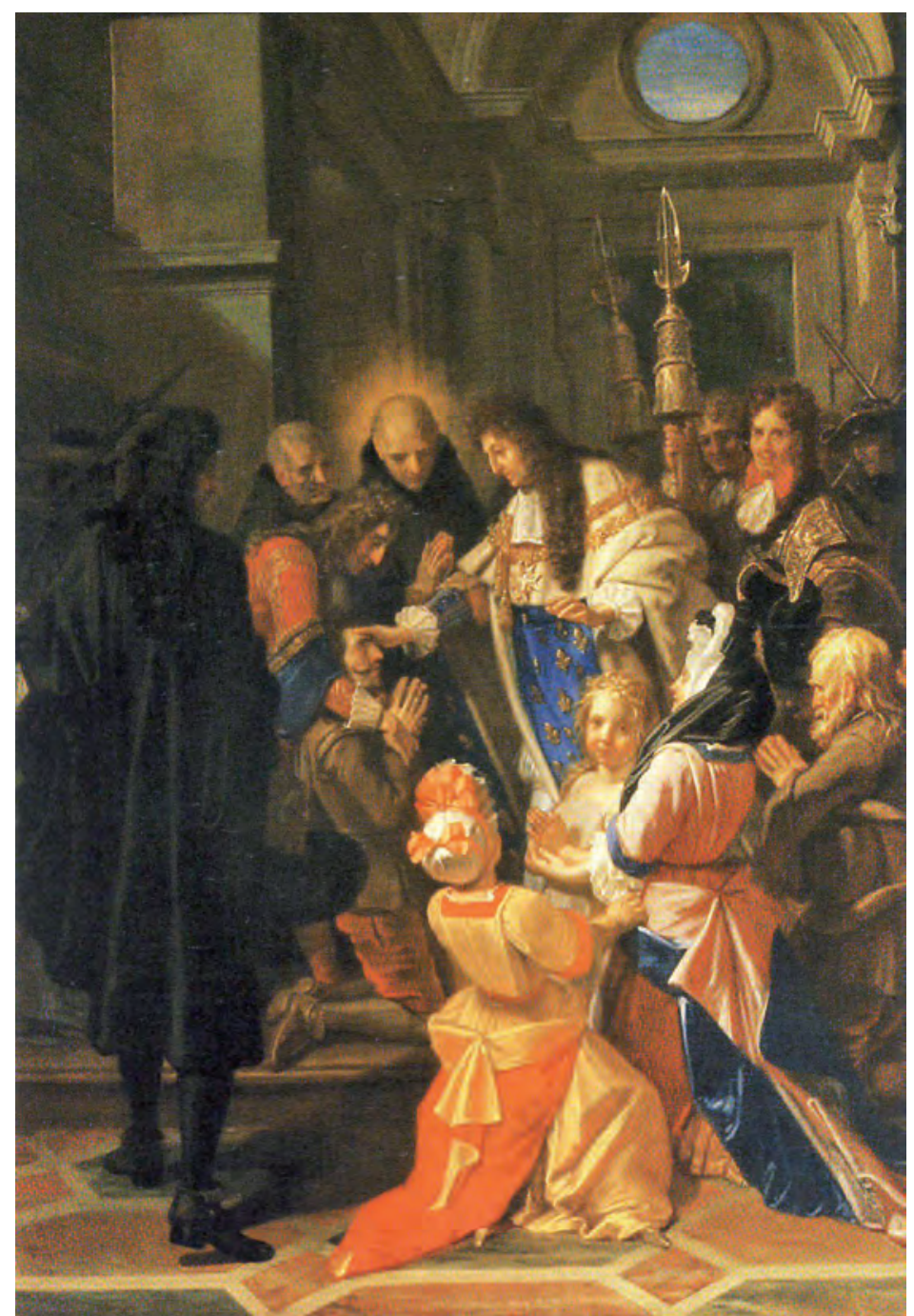

Fig. 8. JeAn Jouvenet, Luis XIV curando la escrófula (Iglesia Abadía de Saint-Riquier, 1690)

curing the disease called the Kings-Evil (Londres, 1679). En la parte superior un grabado de F.H. van Hove nos muestra al monarca en su palacio, sentado en su trono y acompañado de cortesanos y soldados. Frente a él, un enfermo se dispone a ser tocado. En la distancia aguardan otros enfermos y tullidos, y también niños [Fig. 9]. Otro grabado, en este caso de R. White, muestra una imagen muy similar.

En la corte inglesa también hay referencias sobre reinas taumaturgas, e incluso imágenes, como la miniatura La reina María toca a un niño con escrófulas, en el libro Queen's Mary Manual (Biblioteca de la Roman Catholic Cathedral, Westminster). Otro libro editado a principios del siglo xviII, The 


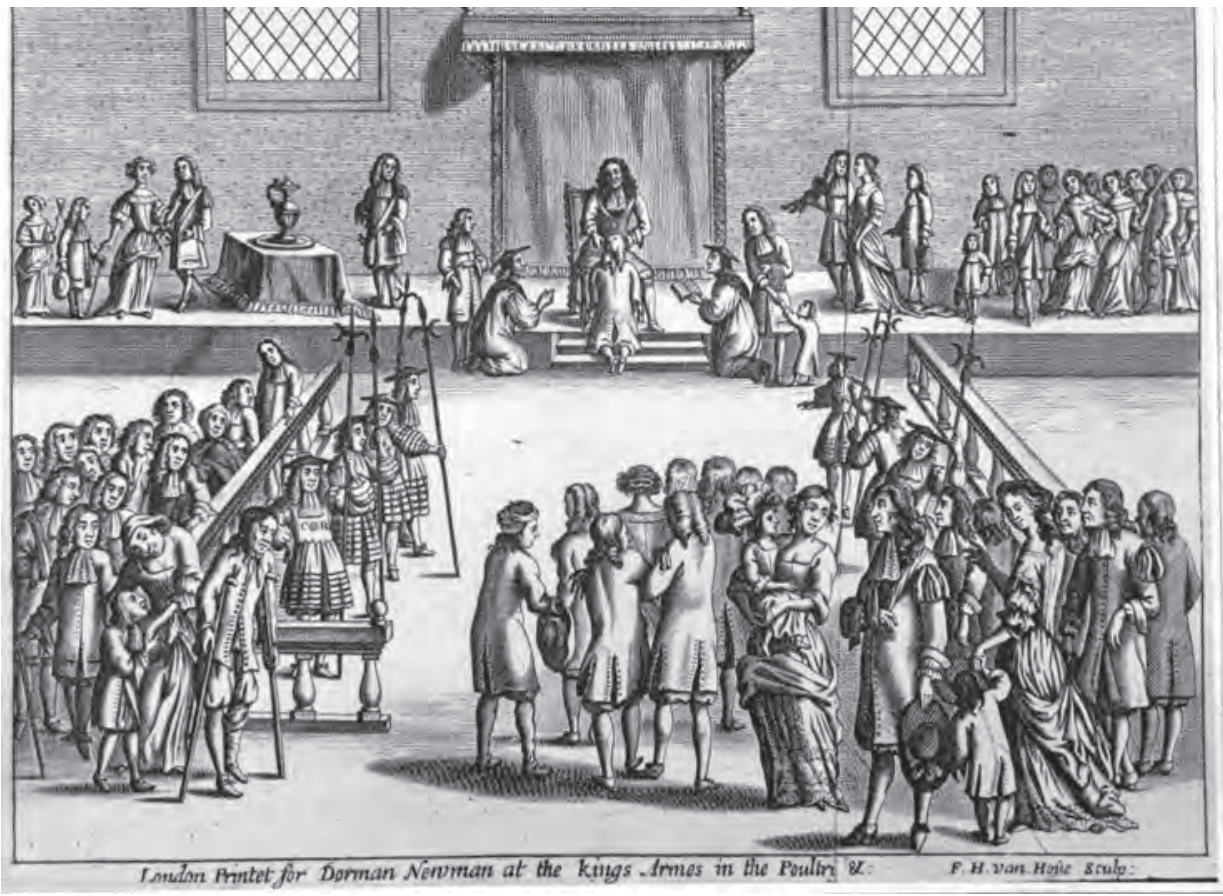

Fig. 9. The Manner of his Majesties curing the disease called the Kings-Evil (Londres, 1679). Grabado de F.H. van Hove

Queen's Famous Progress, or Her Majesty's Royal Journey to the Bath, and happy Return (London, printed for J.W. near Fleet-Street, 1702) narra la jornada de la reina en Bath y Oxford. En Bath fue recibida en una gloriosa y triunfante recepción. Dio limosnas a los pobres, y tocó a muchos por sus males, es decir, actuó como sanadora:

During Her Majesty's saty there, she was pleased to touch several languishing persons of the Evil, a great many coming thither upon that account, who being veiwed by Her Majesty Phisitian, such as was found afflicted with that distemper received tickets according to the usual custome, and was admitted, and touched by Her Majesty, who was Graciously pleased to Order them the usual bounty on this occasion; and bestowed large gifts on poor aged people both there, and all other places through which Her Majesty made Her Progress, to the great joy and admiration of all her loving subjects. ${ }^{24}$

24. The Queen's Famous Progress, or Her Majesty's Royal Journey to the Bath, and happy Return, Londres, printed for J.W. near Fleet-Street, 1702, p. 6. British Library, 1076. L22. Otras Fuentes interesantes sobre el poder taumatúrgico de la realeza inglesa son The Ceremonies for the Healing of them that be Diseased with the King's Evil as they were practised in the time of Henry VII (British Museum, 3407) y WiLliam CLOWES: The Fruitful and Approved Treatise for the Artificial Cure of that Malady called in Latin Struma and in English the Evil cured by the Kinges and Queenes of England, 1602. 
Se conocen también estadísticas de los enfermos curados por los reyes de Francia. Según Marc Bloch, Francisco I tocó en 1528 a 1326 personas, en 1529 a más de 988 , y en 1530, a 1731 como poco. Y las cifras se mantuvieron o incluso aumentaron en los siglos: Luis XIV en 1699 tocó a 3.000 enfermos. Y también tocaron enfermos en sus viajes fuera del reino: Carlos VIII, en Roma y en 1495 tocó en torno a 500 individuos; y Francisco I, prisionero en la corte española tras la derrota de Pavía, tocó a numerosísimos peninsulares. El procedimiento varío poco con los siglos. En la corte francesa, y en días destacados del calendario litúrgico, el rey, tras comulgar, recibía multitudes de enfermos seleccionados por su médico. Durante los reinados de Luis XIII y Luis XIV el rito curativo era anunciado unos días antes, y se celebraba en diversos lugares: si se trataba de París, preferentemente en la galería del Louvre; si transcurría en otra ciudad, en castillos, parques, claustros o iglesias. ${ }^{25}$ Solo las revoluciones políticas y la Ilustración provocaron el desprestigio de esta práctica. En Inglaterra concluyó en 1714 con la llegada al poder de la Casa de Hanover; en Francia fue Luis XVI el último rey taumaturgo.

\section{FUNERALES REGIOS Y MILAGROS EN LA CORTE ESPAÑOLA}

Marc Bloch narra cómo, imitando los poderes curativos de los reyes ingleses y franceses, los apologistas de la Casa de Habsburgo atribuyeron a los reyes de Hungría, a partir del siglo XVI, el poder de curar la ictericia. Un monje suabo, Félix Fabri, afirmaba ya un siglo antes que los condes de la Casa de Austria curaban las escrófulas, la gota y la tartamudez. Pero todo esto no dejaban de ser fábulas eruditas, y lo cierto es que no hubo rituales curativos en las cortes de los Habsburgo. ${ }^{26}$ Por su parte, escritores al servicio de los reyes de Castilla afirmaron los poderes taumatúrgicos de estos. Álvarez Pelayo lo hizo en fechas sorprendentemente tempranas, en torno a 1340, y aseguró que había visto a Sancho II (rey entre 1284 y 1295) curar una endemoniada. Arranca aquí una tradición de presuntos reyes exorcistas que se prolonga hasta el siglo XVII. Marc Bloch opina que probablemente los súbditos castellanos realmente creyeron en el poder de sus monarcas para curar posesiones diabólicas y es posible que hubiera diversas curas aisladas, pero sin constituirse en un rito regular. ${ }^{27}$ Respecto a los reyes de la Casa de Aragón, la taumaturgia se inicia con el cadáver del príncipe Carlos de Viana, al que la creencia popular atribuyó curar sobre su tumba las escrófulas de una mujer en 1461, y posteriormente, a otros pretendidos enfermos. Sin embargo, tampoco en la corte aragonesa existió un ritual regular del toque. ${ }^{28}$

\footnotetext{
25. BLOCH, Les rois thaumaturges, pp. 286-290 y 329

26. Ibidem, p. 142 y ss.

27. Ibidem, p. 147.

28. Ibídem, pp. 148 y 149.
} 
Tal como explica Javier Varela:

[...] los reyes españoles no eran ungidos ni demostraron poderes curativos, como sus colegas franceses o ingleses [...] la crítica más avisada ha señalado que la unción y la coronación -juntas o separadas- eran actos que reforzaban el poder de la Iglesia, pues ella era la que refrendaba la autoridad suprema, y que su ausencia demostraba la fortaleza de la monarquía española moderna, sobre todo en relación a la realeza visigótica aragonesa y castellana medieval (hasta Juan I en 1379), que sí practicaron estas ceremonias.

$\mathrm{y}$ añade respecto a los poderes curativos: $:^{29}$

[...] es cierto que los españoles no curaron públicamente la escrófula -el mal royal francés-, ni transmitieron virtudes medicinales a ningún amuleto -los cramprings ingleses- [...]. A pesar de ello, toda una corriente literaria -subrayamos el término- se empecinó en atribuir a los monarcas hispanos el poder de librar a los posesos. El obispo Álvaro Pelagio es uno de los pocos, si no el único, que cuenta en su Speculum Regum una concreta intervención cumplida por Sancho IV sobre una endemoniada.

Varela recuerda como, pese a ese poder recogido por los propagandistas de los Austrias hispanos incluso en el siglo XVII, ni Carlos V ni sus sucesores practicaron jamás la expulsión de demonios.

Los Habsburgo españoles no poseyeron, en principio, las facultades taumatúrgicas de los reyes de Francia. Y los Borbones hispanos parecen perder ese derecho que les correspondía por herencia cuando se sientan en el trono hispano. Sabemos, sin embargo, de algunos milagros curativos atribuidos a reinas españolas en el contexto de su muerte. Javier Varela da noticia, por ejemplo, de diversos prodigios curativos que tuvieron lugar en el óbito de Mariana de Austria y que fueron atribuidos a su santidad. Asimismo recuerda este investigador cómo Felipe V e Isabel de Farnesio, en su visita al sepulcro de San Isidro, tomaban con sus manos los rosarios de sus súbditos y los entregaban a sus capellanes para que estos tocasen el cadáver del santo con ellos, asumiendo de alguna forma y por medio de la mediación, las virtudes milagrosas de este. ${ }^{30}$

Existieron pues destellos de la taumaturgia real francesa o inglesa en la corona española. Y estos destellos, sumados al culto a los reyes santos y milagreros, y a las dos tradiciones de reyes sanadores clásica y cristiana, permitieron que también en España estuviera presente la imagen ideológica del rey taumaturgo. Esta concepción política y propagandística de un rey capaz de curar esta implícita, en mi opinión y como decía al principio, en el lienzo de Juan Bautista Maíno, La recuperación de Bahía de Todos los Santos (1634-35, Museo Nacional del Prado) [Fig. 10]. Se trata de una pintura realizada para la serie de batallas que

29. JAVIER VARELA: La muerte del rey. El ceremonial funerario de la monarquía española (1500-1885), Turner, Madrid, 1990, pp. 86-87.

30. VARELA, La muerte del rey, pp. 105 y 139. 


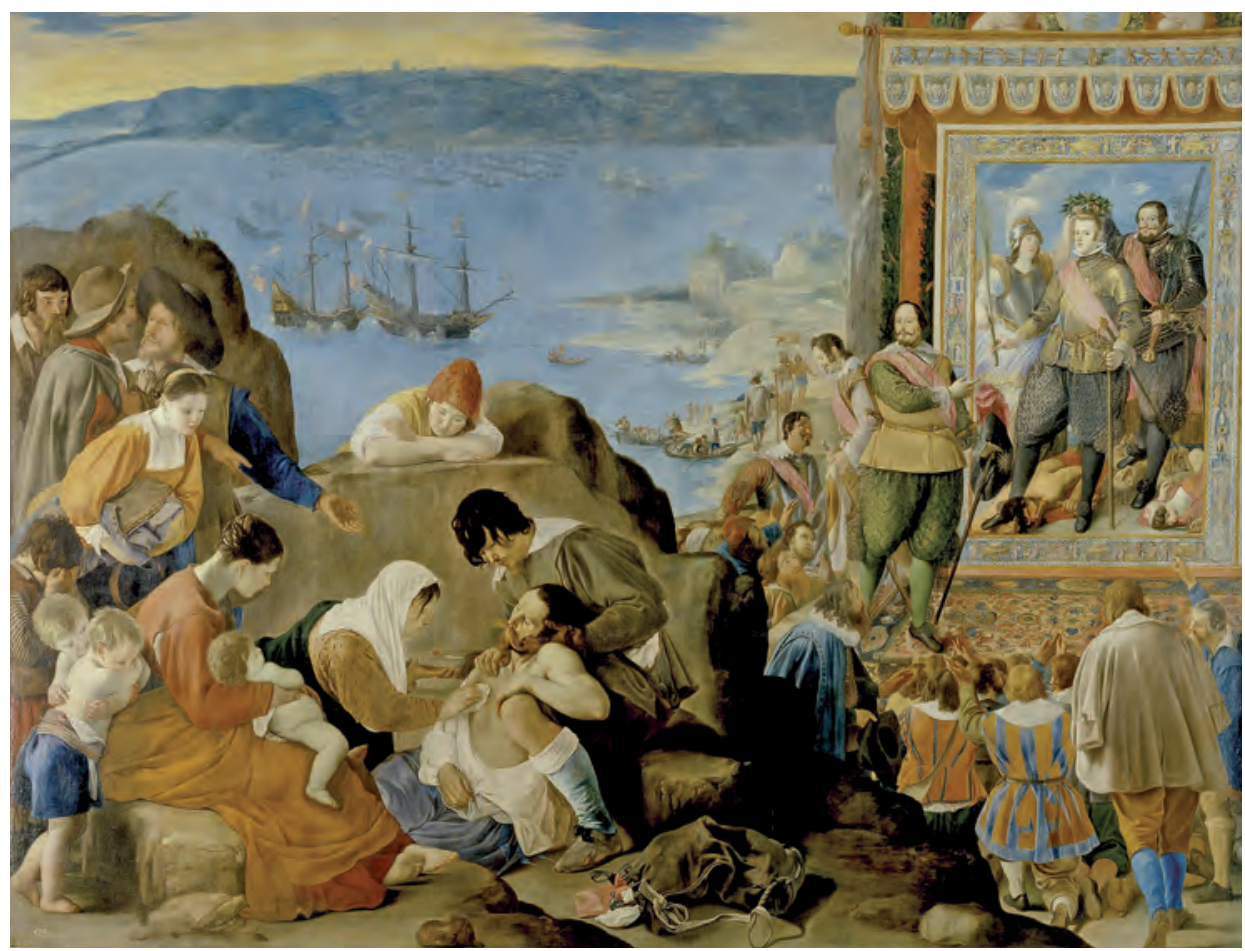

Fig. 10. Juan Bautista Maíno, La recuperación de Bahía de Todos los Santos (1634-35, Museo Nacional del Prado)

decoraba en Salón de Reinos del Palacio del Buen Retiro. Doce cuadros en total encargados a diversos pintores que mostraban victorias de los ejércitos hispanos durante el primer período de la guerra de los Treinta Años (1621-1630). El encargo partió del propio conde-duque de Olivares, responsable del despliegue iconográfico del Salón de Reino, y de la construcción del propio palacio.

A Maíno le correspondió representar la recuperación de la ciudad de San Salvador, en la bahía de Todos los Santos en Brasil en el año 1625, que había sido ocupada por los holandeses el año anterior liderados por el almirante Jacob Willekens. La importancia estratégica de esta ciudad estribaba en que desde aquí se importaba la caña de azúcar a Europa, y por ello el interés de la Compañía Holandesa de las Indias Occidentales por controlar este enclave. El conde-duque de Olivares mandó a los almirantes don Fadrique Álvarez de Toledo y Mendoza y don Manuel de Meneses, y al general don Juan Fajardo de Guevara, al frente de una flota de cincuenta y dos navíos (treinta españoles y veintidós portugueses), y una fuerza de 12.566 hombres y 1158 piezas de artillería. ${ }^{31}$ Los hechos fueron narrados por el soldado Juan de Valencia y Guzmán. ${ }^{32}$

31. Alfonso Rodríguez G. De Ceballos: «La recuperación de Bahía de Todos los Santos» en Leticia Ruiz Gómez: Juan Bautista Maíno. 1581-1649, Museo Nacional del Prado, Madrid, 2009, pp. 180-192.

32. Compendio historial de la jornada del Brasil y sucesos de ella, donde se cuenta cómo se ganó al rebelde holandés la ciudad del Salvador de Bahía de Todos los Santos y de su restauración por las Armas de España (...). Recogida en Colección de documentos inéditos para la historia de España (CODOIN), LV, Madrid, Viuda de Calero, 1870, pp. 43-200. Citada por Rodríguez G. De Ceballos, «La recuperación de Bahía...», p. 183. 
La pintura nos muestra una composición escenográfica dispuesta en varios planos. En primer término contemplamos al soldado herido, asistido por familiares y curiosos. En segundo plano, los holandeses vencidos se arrodillan -a la vez que levantan sus manos- ante un tapiz cobijado por un dosel que muestra a Felipe IV armado, y que sostiene el bastón de mando y la palma de la victoria, siendo coronado de laurel por Minerva y el conde-duque de Olivares. Este último sostiene con la mano libre la espada justiciera y el olivo de la paz. A los pies del monarca se hallan las alegorías de la herejía, la hipocresía y del furor. ${ }^{33}$ El lienzo es mostrado a la multitud por el almirante don Fadrique Álvarez de Toledo desde una tarima alfombrada. En el tercer plano vemos la ensenada con la población de San Salvador dibujada sobre las colinas y la flota española que la ha liberado. Dos galeones en primer plano exhiben sus banderas y disparan sus cañones revistiendo de solemnidad la ceremonia que contemplamos en segundo plano. Sobre el dosel dos angelotes sostienen un mote envuelto en guirnaldas: Sed dextera tua («sino tu diestra»).

Según Alfonso Rodríguez G. de Ceballos, y recuperando una hipótesis de Elías Tormo, no hay duda de que Maíno tuvo presente a la hora de realizar el cuadro el texto de la comedia de Lope de Vega, El Brasil restituido, representada en el Alcázar de Madrid en 1625. La comedia concluye precisamente mostrando a la guarnición holandesa solicitando clemencia ante un retrato de Felipe IV. ${ }^{34}$ Para Julián Gállego el grupo en primer término representaría la caridad cristiana, Jonathan Brown y John Elliott lo vinculan al tema iconográfico de Santa Irene curando a San Sebastián, y Alfonso Rodríguez G. de Ceballos al capitán español herido Diego Ramírez, que desempeñaba un papel importante en la comedia de Lope, rodeado de vecinos portugueses, mostrando de esta manera los beneficios de la Unión de Armas (o unión de reinos y territorios), que propugnaba el conde-duque. ${ }^{35}$ Esta última y atractiva interpretación no se contradice con la que yo propongo: el lienzo de Maíno es asimismo una regiofanía del rey taumaturgo, cuya presencia cura a sus súbditos y a sus reinos. El herido en primer plano es curado por el monarca, sin necesidad de que este le toque. Es la presencia regia la poseedora del poder curativo.

Un emblema reproducido en las emblematas políticas de Juan de Solórzano Pereira (Emblemata centvm, regio politica, Madrid, 1653) y Andrés Mendo (Principe perfecto y Ministros ajustados. Documentos políticos y morales, Lyon, 1662), muestra al dios Apolo derramando en la tierra la hierba panacea desde sus cabellos; abajo una multitud se dispone a recogerlos [Fig. 11]. El lema no puede ser más explícito: Sapientia principis salvs popvli, la panacea que lo cura todo es la sabiduría del monarca. Ni tampoco la letra, de la que selecciono un fragmento:

33. El furor y la hipocresía según la acertada interpretación de Alfonso Rodríguez G. de Ceballos basada en Cesare Ripa. Rodríguez G. De Ceballos, «La recuperación de Bahía», p. 191.

34. Ibidem, pp. 185-186.

35. Ibidem, pp. 187-189. 
El Rey prudente, Apolo al pueblo sea, Llueva su majestad sabiduría,

Con que el súbdito alegre siempre vea

La causa y manantial de su alegría:

De la Panacea logre el gran tesoro

Salud universal, en lluvias de oro.

Apolo, dios de la medicina, aparece en este emblema como modelo de príncipes, de Felipe IV en este caso, pues es el monarca que gobierna España cuando se publican sendas emblematas. Andrés Mendo clarifica aún más el sentido de la imagen: «El rey sabio es la firmeza más estable de su Reyno. Es la pública salud, y remedio de los males». ${ }^{36}$

\section{Sapientia Principis, Salus Populis. EMBLEMA XXI.}

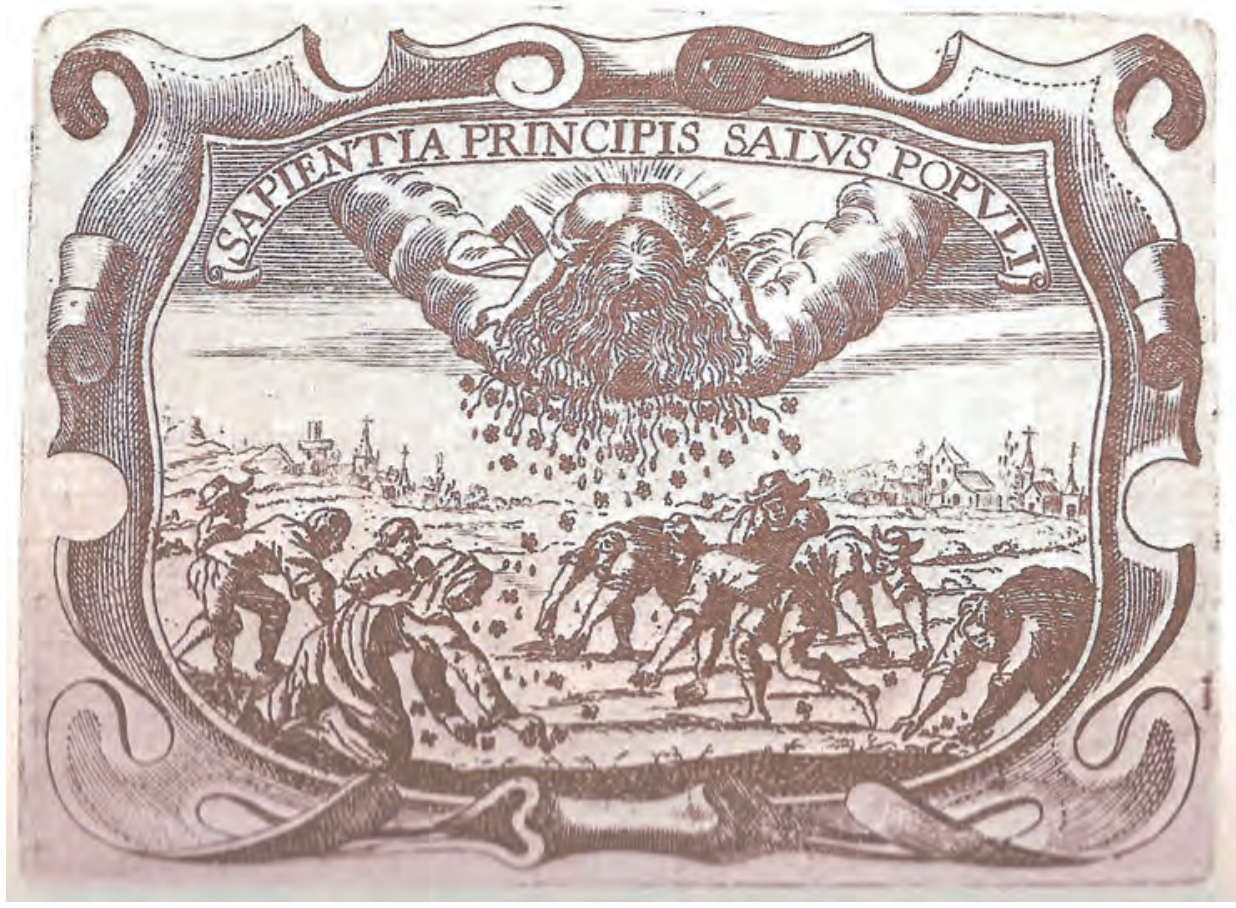

Fig. 11. JUAn de Solórzano Pereira (Emblemata centvm, regio politica, Madrid, 1653). Emblema XXI.

36. Andrés Mendo: Principe perfecto y Ministros ajustados. Documentos políticos y morales, Lyon, 1662 , p. 100. 
Jesús María González de Zárate ha estudiado este emblema, y recuerda que ya Platón (Rep. 489 c) y Aristóteles (Pol. VIII-VI) establecieron la comparación entre el monarca y el médico. Es evidente que en este discurso estamos yendo más allá de la imagen del monarca que cura literalmente las dolencias físicas de sus súbditos y entramos en un discurso más moderno que anticipa los planteamientos ilustrados del siglo XVIII, en los que el rey cura con su buen gobierno los males de la república. El poder curativo se ha trasformado en metáfora de su práctica política. Esta práctica curativa de los males que aquejan al pueblo está también implícita en el lienzo de Maíno, pues es la presencia virtual del monarca en Brasil la que rubrica la victoria de las armas hispanas y la liberación de los cautivos.

\section{ILUSTRACIÓN y Reyes SANAdores}

El discurso ideológico e iconográfico que mostraba a los reyes hispanos como príncipes sanadores que remediaban los males del reino con su práctica de gobierno se acentuó en el siglo de la Ilustración, reflejando el nuevo rumbo que la ciencia política tomaba asimilando las ideas renovadoras que procedían de Francia. El mejor ejemplo plástico de esta nueva concepción de la teoría del rey taumaturgo lo encontramos en el México colonial. En el marco de las numerosas celebraciones públicas organizadas en el virreinato de Nueva España para conmemorar la subida al trono de Fernando VI en 1746, destaca por el interés de sus jeroglíficos el festejo organizado en la ciudad de México por el Real Tribunal del protomedicato. ${ }^{37}$ Quiero referirme ahora a esta serie de emblemas pues constituyen el más completo discurso visual simbólico a favor del rey sanador que podemos encontrar en los territorios de la monarquía hispánica.

El atractivo de estos emblemas urbanos reside en los dos temas seleccionados que estructuran las dos series en que se dividen. La primera serie se diseña en función del arco iris, y todos los jeroglíficos muestran en su cuerpo este fenómeno meteorológico. Coinciden por ello tema y motivo. En la segunda serie encontramos diversos motivos -Esculapio, la serpiente, el centauro Quirón...- relacionados con la ciencia médica y aplicados al monarca, trasformando a Fernando VI en un rey sanador y taumaturgo, capaz de todos los prodigios. Indudablemente pesó mucho en la selección de este segundo asunto el oficio del gremio que financió la fiesta, pero no cabe duda de que más allá de esta motivación concreta, los jeroglíficos del rey sanador entroncan con la construcción ideológica del rey taumaturgo que estamos analizando en esta ponencia y cuya popularidad revela su presencia en los lejanos virreinatos americanos.

37. Véase Víctor Mínguez: «El rey sanador. Meteorología y medicina en los jeroglíficos de la jura de Fernando VI», en JAIme CuAdriello (dir.): Juegos de ingenio y agudeza. La pintura emblemática de la Nueva España, Museo Nacional de Arte de México, 1994, pp. 181-191. 
La fuente que nos permite conocer y analizar ambas series de jeroglíficos es la crónica de J. Gregorio de Campos y Martínez, El iris, diadema immortal... ${ }^{38}$ Se trata de uno de los textos más farragosos y difíciles de entender de toda

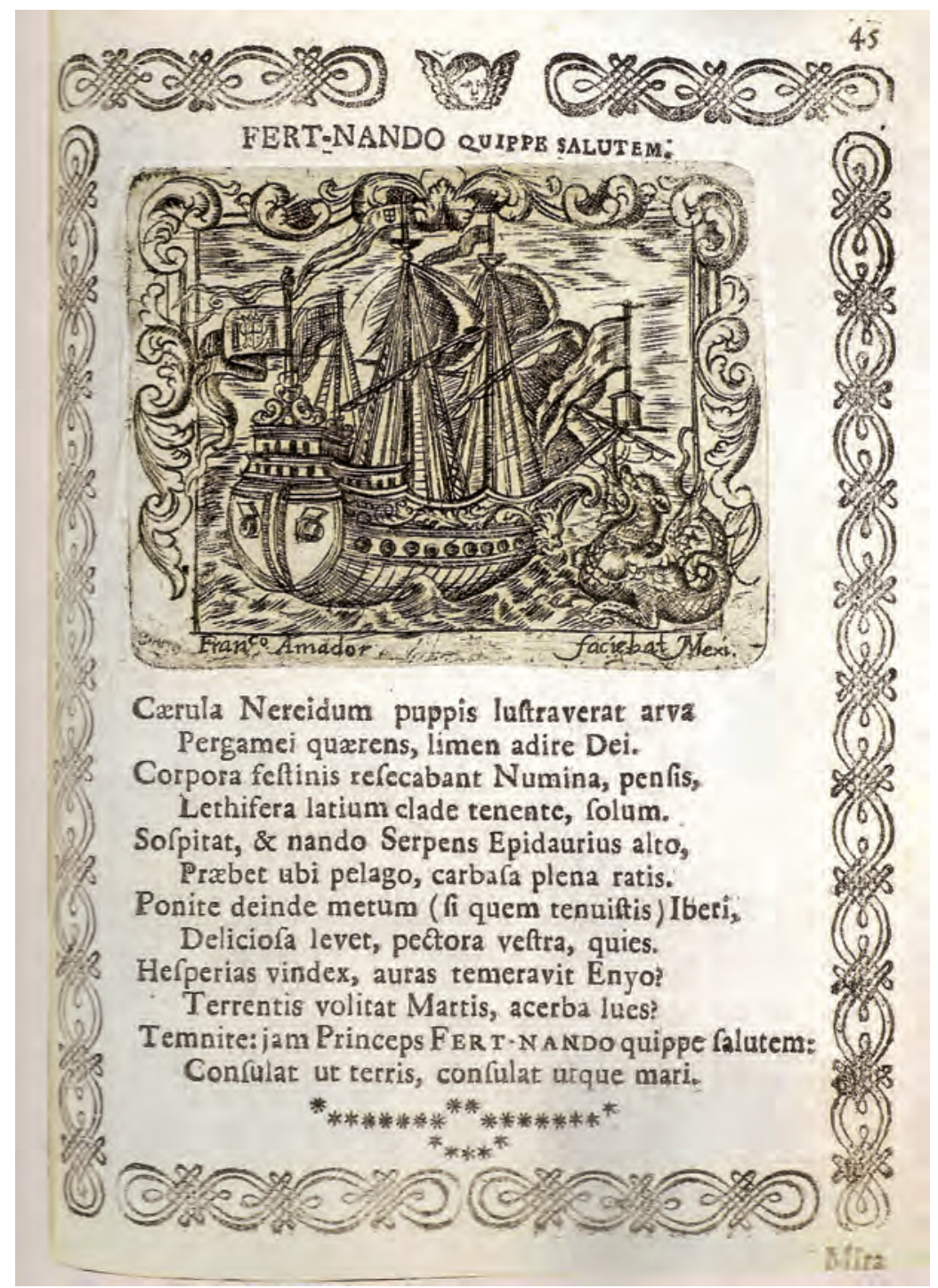

Fig. 12. J. Gregorio de Campos y Martínez, El iris, diadema inmortal, México, 1748. Jeroglífico con barco

38. Su título completo es El iris, diadema immortal. Descripcion de los festivos aplausos con que celebró la feliz elevacion al trono de Nrô. Rey, y Señor el Sr.D. Fernando Sexto, Catholico Monarca de las Hespañas, y Augusto Emperador de las Indias. El real tribunal del protomedicato de esta Nueva Hespaña: a direccion del fidelissimo zelo del Dr. D. Nicolas Joseph de Torres, presidente de dicho Tribunal, y Cathedratico Jubilado de Prima de Medicina, quien le dà à luz para eterno Padron de su lealtad, y la consagra a la reina nuestra señora. Escribiala el Dr. Don Juan Gregorio de Campos, y Martinez, Promotor Fiscal del mismo Tribunal. Con licencia de los superiores: En México, por la Viuda de D. Joseph Bernardo de Hogal. Año de 1748. 
la fiesta mexicana, debido a su confusa prosa. Su principal atractivo estriba en que es el único documento referido al festejo organizado por los médicos novohispanos y, sobre todo, en los ocho emblemas grabados por mano anónima que contiene y que representan los jeroglíficos de la mencionada segunda serie ${ }^{39}$ [Figs. 12 y 13].

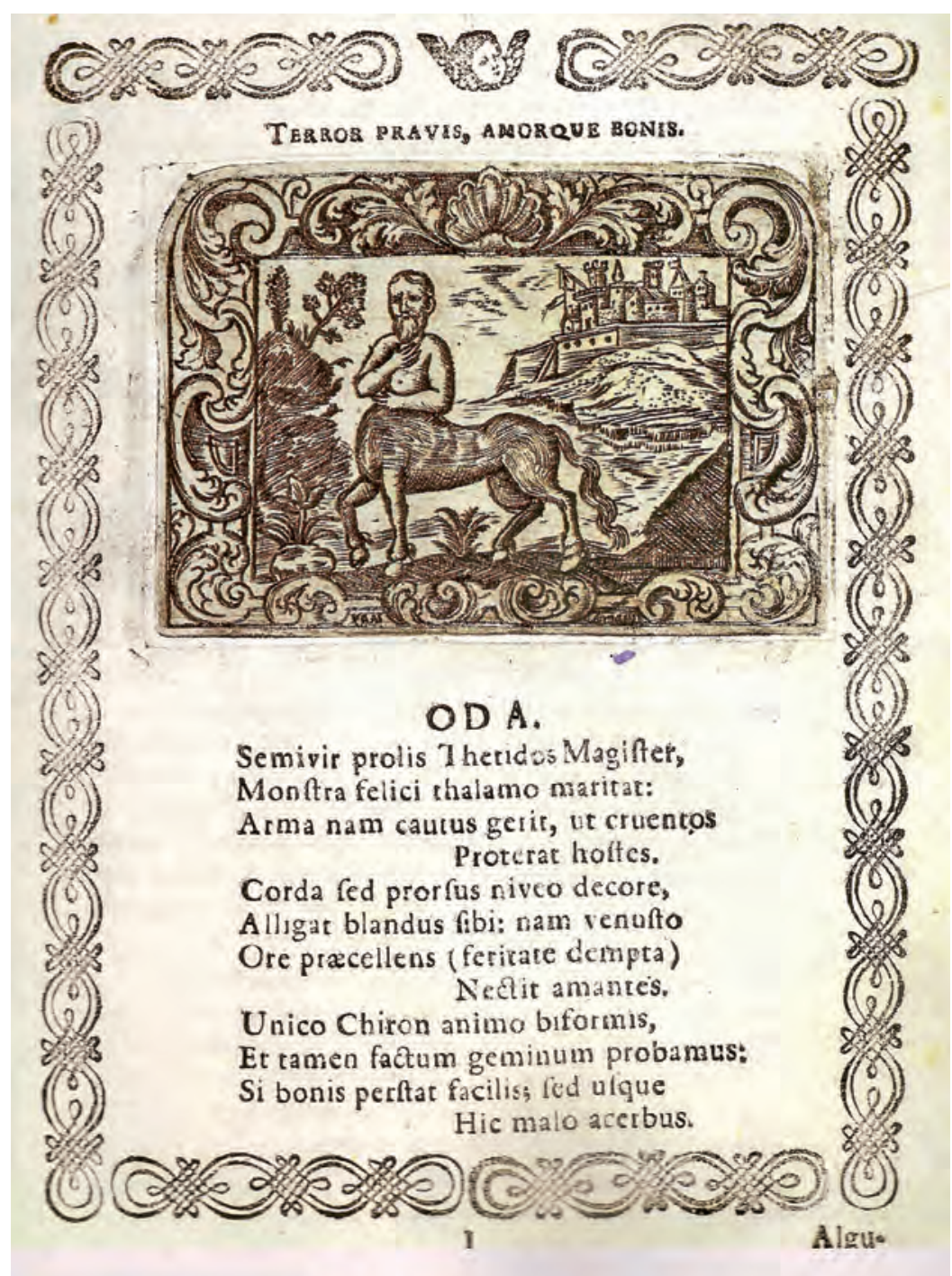

Fig. 13. J. Gregorio de Campos y Martínez, El iris, diadema inmortal, México, 1748. Jeroglífico con centauro

39. Francisco de la Maza los atribuye al grabador Francisco Amador y, con excesiva severidad si valoramos la calidad media del jeroglífico novohispano grabado, los califica de «horribles»: «entre desgano e impericia, el «milagro» que hicieron los pinceles solo quedó en el grabado como un deslucido recuerdo». Véase FrANCISCO DE la MazA: La mitología clásica en el arte colonial de México, México, 1968, p. 196. 
Según nos cuenta Campos, los tres jueces del Real Tribunal del Protomedicato juntaron a «los individuos de los Reinos de la Medicina, Cirugia, Pharmacopea y Phlobotomia, para que formassen los quatro arcos de una Corona" y debatieran su aportación a la fiesta fernandina. Resolvieron disponer luminarias y realizar una función religiosa, fijaron la fiesta en el día seis de diciembre de 1747 y nombraron comisario del acontecimiento al doctor Nicolás José de Torres.

Se eligió como escenario para los oficios religiosos que centraron la celebración la iglesia del Hospital de la Concepción y Jesús Nazareno, por alzarse en el lugar donde Cortés afirmó su victoria sobre los aztecas. Adornaron con luminarias las torres y azoteas desde el palacio real hasta el templo escogido. En la plaza principal de la ciudad levantaron seis castillos ígneos que hicieron estallar entre el tañido de las campanas de la iglesia de Jesús Nazareno. La fachada del templo se adornó de damasco carmesí, y su interior con tapices, damascos, flores y luces, exhibiendo el altar mayor una escultura enjoyada de María. Finalmente, alzaron en el cementerio anexo cuatro arcos de triunfo efímeros, adornados con empresas, odas y epigramas, que el cronista alaba por su belleza y tamaño. Los jeroglíficos fueron ubicados doce en el muro del cementerio -serie del arco iris- y ocho en los frontis de los cuatro arcos -serie médica. Dirigió la disposición de todas las decoraciones el mencionado José de Torres, a quien hemos de suponer asimismo mentor de los jeroglíficos.

Centrémonos en la segunda serie. Los ocho jeroglíficos que decoraron los arcos efímeros mostraron a Fernando VI como médico taumaturgo, poseedor de las mismas virtudes que los que practican la medicina: prudencia, vigilancia, etcétera. Para ello se le representó metaforizado principalmente en Quirón y Esculapio. Quirón fue el más famoso y sabio de los centauros. Educó a algunos de los dioses y héroes más relevantes -como Aquiles, Apolo, Jasón o el mismo Esculapio- en las ciencias de la música, la guerra, la caza, la moral y la medicina. Por haber practicado la cirugía fue considerado un prestigioso médico. Asclepio o Esculapio, hijo de Apolo, fue el principal alumno de Quirón en el arte de la medicina, alcanzando tal habilidad que incluso resucitaba a los muertos, y por ello se convirtió en el dios de esta ciencia.

El motivo del centauro ya lo encontramos en la pintura novohispana en los extraños frescos de la iglesia de Ixmiquilpan, ${ }^{40}$ donde caballeros montados en tigres y águilas luchan contra centauros, o en diversos jeroglíficos que adornaron arquitecturas efímeras en fiestas públicas mexicanas como la que nos ocupa. Así por ejemplo, en el arco de triunfo diseñado por sor Juana Inés de la Cruz para la entrada del virrey marqués de la Laguna y conde de Paredes en 1680, en el arco del poeta Alonso Ramírez de Vargas para la entrada del conde de Valladares en 1696 o en el escenario provisional levantado en Durango para

40. DE la MAZA, La mitología clásica, pp. 46-48. 
la jura de Fernando VI en $1747 .^{41}$ Por su parte Esculapio ya había aparecido también en varias ocasiones en la fiesta mexicana, curiosamente como disfraz: con ocasión del desfile mitológico organizado para la celebración de la canonización de san Ignacio y san Francisco Javier en 1623 en Puebla, ${ }^{42}$ o en la mascarada de carros alegóricos organizada por la Universidad de la Ciudad de México en 1724 con motivo de la proclamación de Luis I. ${ }^{43}$

Además, ambos motivos mitológicos cuentan con precedentes emblemáticos, en los que es más que probable -dada la relevancia de algunas de las fuentes- que el mentor hallara el modelo, o cuando menos la inspiración. Precedentes emblemáticos del centauro son el propio Alciato -emblemas 12 y 145-, Sebastián de Covarrubias - centuria I, emblema 82 y centuria III, emblema 11- o Solórzano -emblema XXXI-, sin olvidar el Sueño de Polifilo, cuyos grabados del primer triunfo muestran varios centauros tirando del correspondiente carro. Esculapio es mucho menos frecuente que Quirón en los libros de emblemas. Sin embargo, Alciato le dedica de nuevo una composición en la que el célebre médico aparece representado por medio de la Serpiente -emblema CXLIX, que lleva el apropiado lema Salvs pvblica.

Además del centauro -dos emblemas- y Esculapio -tres emblemasencontramos también otros motivos, relacionados asimismo con el oficio de la medicina: el jardín, la vasija de laboratorio y el hipopótamo. Sin embargo, no aparece en esta serie el arco iris, pero siempre está presente en las explicaciones que hace Gregorio de Campos de las distintas composiciones, poniéndolo en relación con el motivo de estas por medio de la retórica barroca.

Veamos algún ejemplo. A Esculapio lo encontramos indistintamente personificado, ${ }^{44} \mathrm{o}$ metaforizado en su báculo y la serpiente enroscada.$^{45}$ Este último es el caso del jeroglífico que lleva por mote Junctam cum viribus artem, y que alude a la prudencia de Fernando VI. Su letra:

41. Véase sor JUANA INÉS DE LA CRUZ: Neptuno alegórico, océano de colores, simulacro politico, que erigió la Iglesia Metropolitana de México en las lucidas alegóricas ideas de un arco triunfal, que consagró a la entrada del Conde de Paredes (...), 1725, A. RAmírez VARgas: Zodiaco illvstre de blasones heroycos, gyrado del Sol politico, imagen de principes que occvltó en su Hercules thebano la Sabiduria mythologica (...), México, 1696 y Hercules coronado, que a la augusta memoria, a la real proclamacion, del prvdentissimo, serenissimo, y potentissimo señor D. Fernando VI, rey de las Españas (...), México, 1749. En las tres ocasiones aparecen los centauros en función del mito de Hércules.

42. Citado por Santiago Sebastián en El barroco iberoamericano. Mensaje iconográfico, Madrid, 1990, pp. 284 y 285.

43. Véase C. Ruíz Guerra: Letras felizmente laureadas y laurel festivo de letras con ocasión de la jura de nuestro amado rey Luis Fernando el primero, brotó a influjos, no a golpes de Minerva, en el celeste suelo de su Real y Pontificia Academia, Atenas de las Indias Septrentrionales (...), México, 1724. Este disfraz lo exhibieron, por supuesto, los estudiantes de medicina.

44. La representación emblemática de Esculapio personificado no es una novedad. Así lo muestra J. SAmbucus: Emblemata, et aliquot nummi antiqui operis, Antuerpiae, 1564, emblema 203. Sambucus lo presenta como un anciano barbado - similar a la figura del jeroglífico mexicano-, cubierto con sombrero de peregrino y sosteniendo con la mano la cabeza de la gorgona.

45. La identificación del dios con la serpiente aparece ya recogida en la Iconología de CesARE RiPA. La alegoría de la medicina exhibe el bastón con el reptil enrollado, afirmando que es «la enseña de Esculapio». 


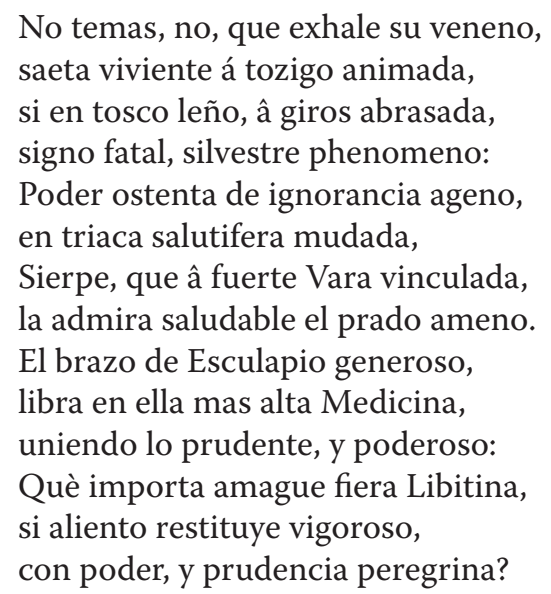

Otro jeroglífico mostraba sobre un paisaje un orbe, y por encima de este el signo zodiacal de Sagitario sobre un arco, en una compleja referencia al carácter benigno de la medicina -centauro Quirón-y al amor del monarca por sus vasallos -dardos. Lleva por lema Totique salutifer orbi, y por letra:

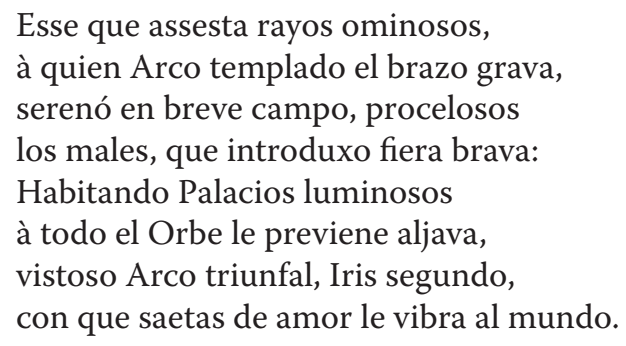

Por supuesto no hay que entender los programas médico-meteorológicos confeccionados para la jura de Fernando VI y su mezcla de elementos mitológicos y celestes como una manifestación de medicina primitiva, medicina mágica o falsa medicina. ${ }^{46}$ Precisamente el siglo XVIII, y pese a los numerosos prejuicios que la amenazaban, la ciencia médica vive un importante desarrollo: florecen las escuelas -como las de Leiden, Edimburgo y Viena-, se clasifican las enfermedades, se producen avances importantes como el descubrimiento de la vacuna contra la viruela o el nacimiento de la ortopedia y se publican tratados científicos tan válidos como el libro del alemán Stahl, Theoria medica vera (1708), los estudios anatómicos del italiano Morgagni y del francés Bichat, los análisis fisiológicos del suizo Von Haller o las posteriores investigaciones de Hoffmann, William Cullen, John Brown, Benjamin Rush, Hahnemann y otros muchos. Algún científico defendió la influencia de los astros en las enfermedades y el hipnotista Mesmer afirmó en su tesis sobre

46. Sobre la relación entre la medicina y la magia en el México virreinal véase el trabajo de GonzALO Aguirre Beltrán: Medicina y magia. El proceso de aculturación en la estructura colonial, México, 1963. 
el «magnetismo animal» el poder astral, pero lo cierto es que en el campo de la experimentación científica astrología -y meteorología- y medicina se distancian en el Siglo de las Luces. ${ }^{47}$

La simbología de la jura novohispana de Fernando VI tiene una intención meramente ideológica. La propaganda áulica y la retórica mitificadora de los reyes hispanos en las fiestas virreinales tendía a construir imágenes apoteósicas de estos, y en esta ocasión se ofreció una metáfora visual que enlazaba con la retórica barroca de los reyes taumaturgos -recordemos que Fernando VI era un monarca borbón, procedente de la casa de Francia - y que se fundamentaba en dos posicionamientos políticos contemporáneos. Por un lado el paternalismo de los monarcas ilustrados, que impulsaron el desarrollo de la ciencia médica preocupados por la salud física de sus súbditos y deseosos de aliviar sus sufrimientos. Ello justificaba la devoción de los médicos novohispanos y la especial iconografía que diseñaron. Por otro lado, y aún más interesante, fue el concepto ideológico del rey cirujano que cura los males -ya no solo físicos, sino morales, políticos, económicos, etcétera- de su reino, y que coincidía con los planteamientos argumentales de otras metáforas reales codificadas y divulgadas por los libros de emblemática y los jeroglíficos urbanos, como el príncipe timonel o el rey Sol. Los distintos motivos empleados en los jeroglíficos médicos fueron aprovechados para cantar las virtudes del nuevo monarca: vigilancia, prudencia, diligencia, benignidad, justicia, etcétera.

\section{REVOLUCIÓN, MEDICINA POLÍTICA Y GUILLOTINA}

Sin embargo, los reyes ilustrados y taumaturgos no fueron capaces de intuir y mucho menos evitar el huracán revolucionario que se abatió sobre Europa en la última década del siglo XVIII, y en el nuevo orden impuesto por la Revolución francesa desde 1789 hasta 1794 no hubo espacio para reyes curadores. Se ignora en qué momento concreto Luis XVI de Francia dejó de ser un rey taumaturgo, pero el descrédito en que había caído esta práctica durante la Ilustración hizo que dejaran de organizarse los rituales curativos regios durante su reinado (en Inglaterra habían finalizado medio siglo antes), y desde luego cuando estalla la Revolución -y sobre todo cuando huye a Varennes- el rey acaba perdiendo a los ojos de la multitud sus restantes carismas, poderes y cualidades.

Pese a todo, la Revolución puso en marcha su propio ceremonial sanitario, aunque centrado en la salud política y con consecuencias sangrientas. Me estoy refiriendo a las ejecuciones masivas de aristócratas, moderados, exiliados y traidores por medio de la nueva máquina de matar, la guillotina. Si durante el siglo XVIII y como hemos visto se presenta a los monarcas como príncipes sanadores que por medio de la Ilustración pretenden curar las dolencias del

47. José BABINI: Historia de la Medicina, Barcelona, 1980. 
pueblo, ahora los líderes revolucionarios cortan de raíz los miembros enfermos de la sociedad que pretenden liberar. De alguna manera, el espectáculo de reos políticos guillotinados es el reverso de la moneda del antiguo ceremonial taumatúrgico de los reyes franceses. El primero se cimenta en el poder mágico del monarca; el segundo en la superioridad moral del gobierno republicano. Ambos pretenden sanar al pueblo, y ambos convierten el rito en un espectáculo de masas.

Como es sabido la guillotina fue inventada precisamente por un médico, el diputado Joseph-Ignace Guillotin, que en diciembre de 1789 la presentó ante la Asamblea: una máquina rápida, indolora e igualitaria para causar la muerte de los condenados en gran número, frente a la lenta, dolorosa y discriminatoria agonía de los reos sometidos a la horca, al descuartizamiento o a otros métodos tradicionales de ejecución. Inicialmente se ubicó en París en la place de Grève, posteriormente en la place du Carrousel, y finalmente en la place de la Concorde ${ }^{48}$ La guillotina se extendió por toda Francia -solo en 1794 fueron ejecutadas 40.000 personas-, y por las posesiones francesas en América. Sus grandes puestas en escena tuvieron lugar con las ejecuciones de los monarcas -Luis XVI, el 21 de enero de 1793, y María Antonieta, el 16 de octubre del mismo año-y posteriormente las de los principales líderes revolucionarios: Hébert, Danton, Desmoulins, el duque de Orleans, Saint-Just o Robespierre. Incluso David dejó testimonio de estos acontecimientos -María Antonieta camino de la guillotina- en un famoso dibujo [Fig. 14].

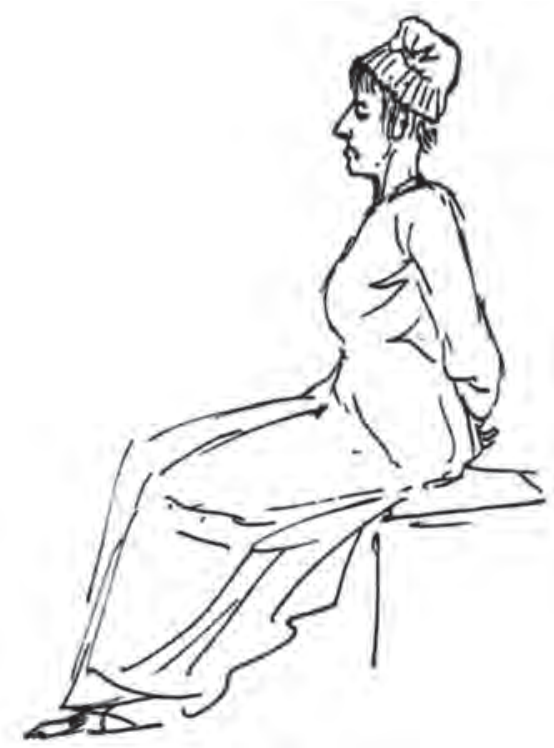

Fig. 14. DAvid, María Antonieta camino de la guillotina, dibujo 


\section{EL EMPERADOR CURATIVO}

Tras el fin de la revolución en 1794, el viejo poder taumatúrgico de los reyes de Francia no será olvidado. Napoleón Bonaparte, general victorioso, cónsul y finalmente emperador, construirá su iconografía a partir de dos circunstancias contrapuestas y paradójicamente complementarias. ${ }^{49}$ Por un lado, Bonaparte, hijo de la revolución que ha cambiado el mundo para siempre, es la imagen de un hombre que se ha hecho a sí mismo en el campo de batalla, carente de los privilegios de clase de la decadente aristocracia y que ha alcanzado el trono de Francia gracias solo a sus virtudes y cualidades personales. Por otro lado, Napoleón buscará su legitimidad y la de su familia estableciendo nexos con el pasado histórico: es un genio militar similar a Aníbal o Alejandro, se coronará con la corona de Carlomagno y en presencia del Papa, se casará con una princesa de la rancia Casa de Habsburgo, o tendrá poderes curativos como la destronada realeza francesa. Este poder curativo se manifestará en Napoleón cuando todavía es general, y como le sucediera a Vespasiano, aflorará al pisar Oriente, o más concretamente, el Egipto mameluco.

$\mathrm{Al}$ frente de una flota de más de trescientos barcos -la mayor que se había visto desde la batalla de Lepanto-, y cuarenta mil hombres, Napoleón llega a Egipto el 1 de julio de 1798, estableciendo su gobierno en El Cairo. En diciembre de ese año brota la peste en Alejandría, seguramente procedente de Constantinopla. La cuarentena a la que se somete la ciudad no consigue evitar su expansión. ${ }^{50}$ En enero de 1799 Napoleón decide invadir Siria. La peste vuelve a alcanzar al ejército francés en Jaffa, procedente en esta ocasión del interior de la ciudad. ${ }^{51}$ Inicialmente se negó la existencia de la enfermedad, pero la mortandad -entre setecientos y ochocientos hombres- obligó a reconocerla y la moral de las tropas se derrumbó. Ante el pánico desatado, Bonaparte «que a aquellas alturas confiaba ya plenamente en su destino personal, y quizá queriendo exhibir poderes extraordinarios», visitó a los enfermos instalados el 11 de marzo en un hospital ubicado en un monasterio armenio del siglo XVII. ${ }^{52}$ Philip Dwyer recoge en su moderna y atractiva biografía sobre Bonaparte el testimonio del oficial médico en jefe, Nicolás René Desgenettes:

El general recorrió las salas y sus anexos, habló con prácticamente todos los soldados lo bastante conscientes como para poder oírlo y, durante una hora y media, con toda la calma, se interesó por los detalles de la administración. Encontrándose en una sala abarrotada, ayudó a levantar, o más bien a transportar,

49. Víctor MíngUeZ: «La iconografía del poder. Fernando VII y José I. Apoteosis y escarnio en la disputa del trono de España», en Alberto Ramos Santana y Alberto Romero Ferrer (eds.): 1808-1812: Los emblemas de la libertad, Universidad de Cádiz, Cádiz, 2009, pp. 161-189.

50. Philip Dwyer: Napoleón. El camino hacia el poder 1769-1799, La Esfera de los Libros, Madrid, 2008, p. 410.

51. Paul Strathern: Napoleón en Egipto, Planeta, Barcelona, 2009, pp. 402-403.

52. DWYER, Napoleón, p. 445. 
el espantoso cadáver de un soldado cuyo uniforme hecho harapos estaba manchado por el estallido espontáneo de un enorme ganglio lleno de pus..$^{53}$

Según Dwyer, el gesto de Napoleón no fue gratuito, sino propagandístico, teatral y racional. Se trataba de demostrar al numeroso grupo de soldados y oficiales que contemplaron la escena, que el miedo estimulaba la enfermedad, mientras que el valor preservaba de ella. Testigos del suceso testimonian el efecto positivo y tranquilizador que tuvo en el ejército. ${ }^{54}$ Paul Strathern, que ha escrito la última monografía sobre la campaña de Bonaparte en Egipto, vincula como posibilidad este «acto de orgullo desmedido, o de valentía suprema, ayudado por una creencia errónea en el poder de la voluntad y en una presuntuosa confianza en sí mismo» con la atroz matanza de cuatro mil prisioneros de la guarnición de Jaffa ordenada el día anterior. ${ }^{55}$ Valor compensatorio causado por los remordimientos por la masacre. Evidentemente, las razones últimas del valor del general francés no podemos saberlas, pero es significativo que, como en el caso de Vespasiano, Napoleón se dota de poderes taumatúrgicos a su llegada a Oriente.

Antoine-Jean Gros recrearía este episodio dejándose llevar por la imaginación en el lienzo Bonaparte, comandante en jefe del ejército de Oriente, en el momento de tocar una buba en el hospital de Jaffa (1804, Louvre) [Fig. 15]. Recordemos que Gros es el pintor napoleónico por excelencia, el artista que junto con David más contribuirá a construir y representar el mito de Bonaparte desde que, por mediación de Josefina de Beauharnais, consiguió realizar su primer retrato del joven general en 1797, Napoleón sobre el puente de Arcola, del que existen varias versiones. Sus posteriores retratos y sus grandes lienzos de batallas le convierten en el cronista visual más efectivo de la epopeya imperial. ${ }^{56}$ En la pintura que nos interesa ahora podemos contemplar una multitud de enfermos y moribundos, desnudos y amontonados, en las naves y patios de un edificio orientalista. A través de los arcos apuntados y más allá de las arquitecturas se descubre en lo alto de la colina la ciudad de Jaffa, sobre la que ondea la bandera francesa. En el centro de la composición, el general Bonaparte se dispone efectivamente a tocar la buba en la axila de un asombrado enfermo. Tras él se halla el médico en jefe del ejército expedicionario, Desgenettes, que protege su aliento con un pañuelo a la vez que intenta sacar de la estancia a Napoleón. A los pies de este un oficial enfermo intenta detener el valiente gesto de su general. A la izquierda del cuadro un cirujano musulmán se dispone a abrir el tumor de otro paciente. Según recoge Albert Boime, el catálogo de la exposición del Salón de 1804

53. Clément de La Jonquière: L’Expedition d'Egypte (1798-1801), 5 vols. Charles-Lavauzelle, París, 1899-1907, vol. IV, p. 284. Citado por Dwyer, Napoleón, pp. 445-446.

54. DWyer, Napoleón, p. 446.

55. Strathern, Napoleón en Egipto, p. 404.

56. Sobre la relación entre Gros y Napoleón véase DAVID O’BriEn: Antoine-Jean Gros, peintre de Napoléon, Gallimard, París, 2006. 
afirmaba que el valor sin precedentes demostrado por Bonaparte había sido imitado desde entonces, y que evidenciaba la magnitud de su benevolencia. ${ }^{57}$ Gros no formó parte de la expedición científica y artística que acompañó a Napoleón a Egipto, y no pudo por tanto contemplar en persona los sucesos de Jaffa, pero sí estuvo en Alejandria Dominique Vivant Denon, cortesano, diplomático y grabador, autor del Voyage dans la Basse et la Haute Égypte, que el 19 de noviembre de 1802 es nombrado director del Museo Central de las Artes y que fue el gran impulsor del renovado Salón de 1804, y en cierta manera el que definió la nueva pintura de historia al servicio de la propaganda que se inicia con el lienzo de Gros..$^{58}$ Precisamente esta pintura intenta contrarrestar la propaganda antibonapartista, muy crítica con la campaña de Egipto, y especialmente con dos episodios: la masacre de prisioneros mencionada y el posterior abandono en que Napoleón deja a sus soldados en Oriente; ambas denuncias son desmontadas en la pintura. Denon asesora a Gros, especialmente en la recreación orientalista. Los propios recuerdos de Gros del asedio de Génova por parte del ejército austriaco también imprimen realismo y crudeza al lienzo. ${ }^{59}$

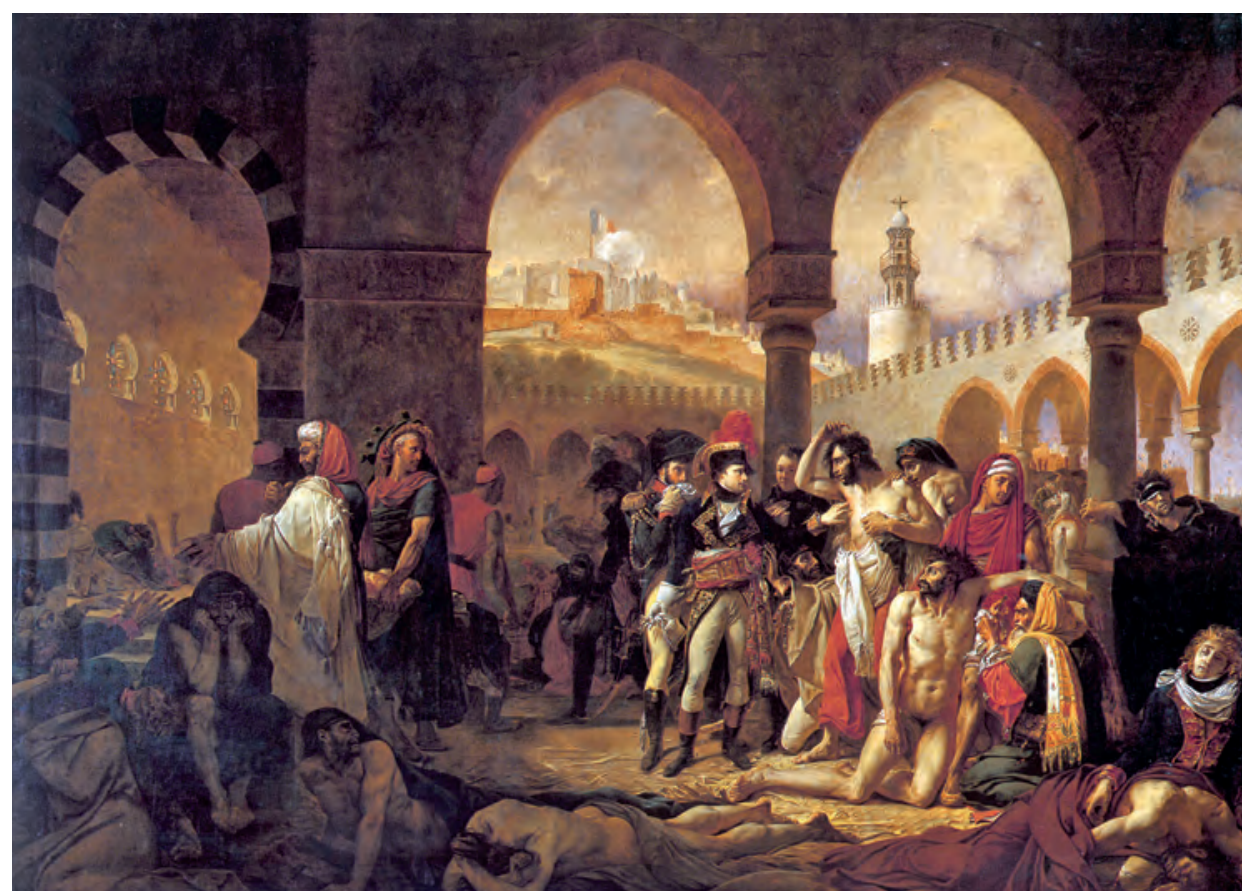

Fig. 15. Gros, Bonaparte, comandante en jefe del ejército de Oriente, en el momento de tocar una buba en el hospital de Jaffa (1804, Louvre)

57. Albert Boime: El arte en la época del bonapartismo, 1808-1815, Alianza, Madrid, 1996, p. 111. 58. O'Brien, Antoine-Jean Gros, pp. 92-117.

59. JeAn Leymarie: La pintura francesa. El siglo XIX, Skira-Carroggio, Barcelona, 1995, p. 48. 
Walter Friedlaender estudió hace años el dibujo original de Gros previo al gran lienzo, Les Pestiférés de Jaffa (Museo del Louvre), donde advertimos como inicialmente el pintor retrata a Napoleón trasladando directamente con sus brazos el cuerpo desnudo de un moribundo. Esta representación era más cruda y a la vez más fiel al relato de Desgenettes, pero no permitía establecer un nexo entre el valiente general y el poder legitimador del toque real. ${ }^{60} \mathrm{La}$ misma composición advertimos en otro boceto conservado, Bonaparte visitant les pestiférés de Jaffa (1804, New Orleans Museum of Art) en el que, además de mostrar al general transportando en persona al apestado, las paredes de la habitación sirven de apoyo a numerosos enfermos y cadáveres que rodean al grupo central.

En la gran pintura de Gros la exaltación de Napoleón adquiere un tinte prerromántico, pues no es su genio militar ni sus cualidades de gobernante los aspectos que se destacan del joven general durante su campaña de Egipto, sino su sentimiento y su sufrimiento por sus soldados enfermos. Gros rodea a Napoleón de una humanidad desagradable, enferma, moribunda, a la que él se dispone a sanar por medio del «toque», por el poder taumatúrgico de los reyes de Francia reencarnado en su persona. Es indudable, por lo tanto, que el discurso propagandístico del lienzo persigue dos objetivos: destacar el valor y la benevolencia del joven general, y legitimar sus aspiraciones políticas a liderar la todavía república francesa mediante la exhibición de poderes reservados a la realeza. Napoleón, como los antiguos reyes franceses, poseía un poder divino.

Conviene advertir que este no es el único lienzo de Gros protagonizado por el gesto del emperador de Francia rodeado por una multitud sufriente. En dos lienzos de batallas realizados por este pintor, La batalla de las pirámides, 21 de julio de 1798 (Versalles, 1810), y Napoleón en Eylau, 9 de febrero de 1807 (Museo del Louvre, 1808), Napoleón, montado a caballo y rodeado por su séquito en medio del campo de batalla, levanta su mano mientras a sus pies se hacina una humanidad moribunda formada por cadáveres, heridos, prisioneros y desposeídos. Su gesto clemente y decidido, tranquiliza y reconforta a las víctimas de la guerra. Se trataría en ambos casos de una taumaturgia no basada en el toque sino en el gesto, en la presencia, en la línea del lienzo de Maíno. Al margen de Gros otros pintores reprodujeron el gesto de Napoleón ante sus soldados heridos tras una batalla, como Charles Meynier en el lienzo Regreso de Napoleón a la isla de Lobau tras la batalla de Essling el 23 de mayo de 1809 (Versalles, 1812) o Jean-Baptiste Debret, Napoleón rinde homenaje al valor malherido, octubre de 1805 (Versalles, 1806).

Hay que añadir finalmente que en fechas próximas a las que Gros realiza sus cuadros de Jaffa y Eylau, o Meynier el de Essling, se siguen pintando en Francia representaciones de San Luis atendiendo a los enfermos, como el lienzo de Guillaume Guillon, llamado Lethière, Saint Louis visitant les

60. WAlter Friedlaender: «Napoleon as «Roi Thaumaturge», en Journal of the Warburg and Courtauld Institutes, vol. 4, n. 3 y 4, 1941-1942, pp. 139-141. 
pestiférés dans les plaines de Carthage (último cuarto del siglo XIX, primera mitad del xix, Museo de Bellas Artes de Bordeaux) [Fig. 16], en el que volvemos a encontrarnos un tema que ya vimos en pinturas del siglo xviI y que es muy próximo iconográficamente al que Gros pinta sobre el hospital de Jaffa: en 1270 y frente a Cartago, la peste se extiende por el ejército cruzado; quinientos años antes que Napoleón, San Luis, rey de Francia, también visitará valientemente a sus soldados moribundos y atiende personalmente a uno en presencia de los demás, proporcionándoles la moral que necesitaban.

No obstante, en la ceremonia de coronación imperial Napoleón rehusó practicar el ritual taumatúrgico del toque de las escrófulas, para evitar vincularse excesivamente al recuerdo de los reyes borbones. Napoleón, la república, el Imperio francés y por supuesto la revolución eran herederos del Siglo de las Luces, y en este caso la contradicción con las prácticas mágicas era insalvable. El lienzo de Gros era una sutil referencia legitimadora que no implicaba en absoluto la recuperación de un rito ya absolutamente desfasado. ${ }^{61}$

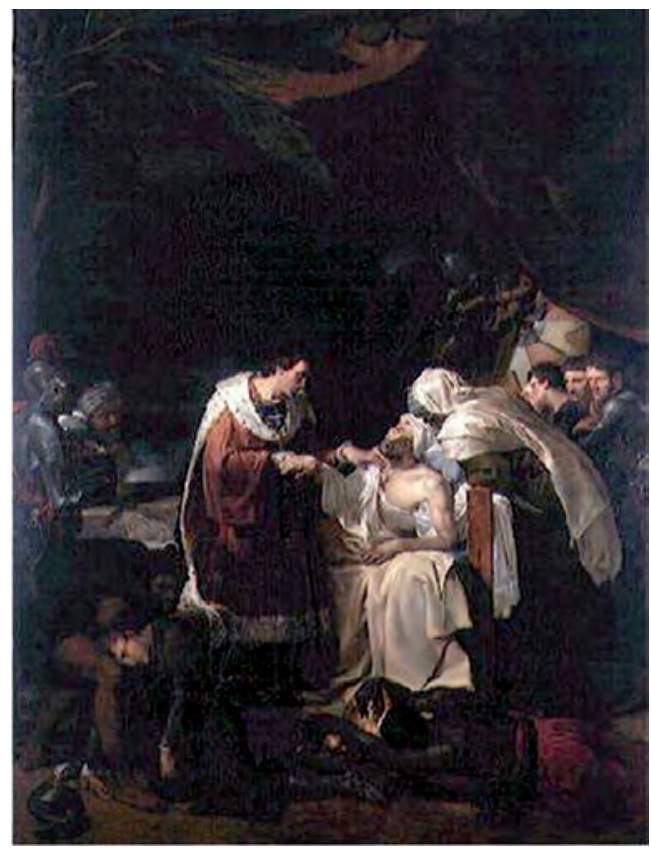

Fig. 16. Guillaume Guillon, Saint Louis visitant les pestiférés dans les plaines de Carthage (último cuarto del siglo XIX, primera mitad del xIx, Museo de Bellas Artes de Bordeaux)

61. Dimitri Casali y David Chanteranne : Napoléon par les peintres, Seuil, París, 2009, p. 37. 


\section{Epílogo}

Vespasiano, Felipe I Capeto, Enrique II Plantagenet, Luis XIII, Luis XIV y Napoleón fueron, junto a otros muchos, reyes y emperadores taumaturgos. También lo fueron en la corte española, por lo menos en el ámbito de las artes y de la propaganda, Felipe IV, Carlos II o Fernando VI. El rey sanador fue un artefacto cultural e ideológico que se remonta a las culturas más primitivas y que perduró durante milenios en el occidente cristiano. Aun contando en las crónicas medievales peninsulares con los precedentes de pretendidas curaciones regias, los Austrias hispanos no fueron capaces de desarrollar un aparato ceremonial de gran alcance social como el que existía en las cortes de Londres o París desde la Baja Edad Media. Sin embargo, una monarquía católica como la española encontró en la capacidad milagrera de los reyes santos y en supuestos prodigios atribuidos a cadáveres regios durante el siglo XVII, así como en la práctica del gobierno ilustrado a lo largo del XVIII, los fundamentos a partir de los cuales fabricar esta imagen del rey sanador de tanto éxito en Inglaterra y Francia. Los retratos de reyes hispanos con iconografía de santos, el lienzo de Maíno y los jeroglíficos novohispanos fernandinos son plasmaciones visuales del poder taumatúrgico que también detentó como hemos visto, aunque más sutilmente, la realeza hispana. Un poder sobrenatural que permitió a ambos lados de los Pirineos, mediante la contemplación de la imagen del rey, el contacto con su cuerpo muerto o directamente el toque curativo, sacralizar a las monarquías cristianas europeas, pues compartían con la divinidad el poder mágico de otorgar la salud. En todas estas representaciones -el relato de las curaciones de Vespasiano, el lienzo de Maíno, la ceremonia francesa de las escrófulas, los jeroglíficos novohispanos, las imágenes de Napoleón en el hospital de Jaffa- la figura del médico adopta los roles de intercesor y testigo del poder sanador de la realeza. Su presencia certifica el prodigio y acrecienta con su subordinación la imagen del monarca.

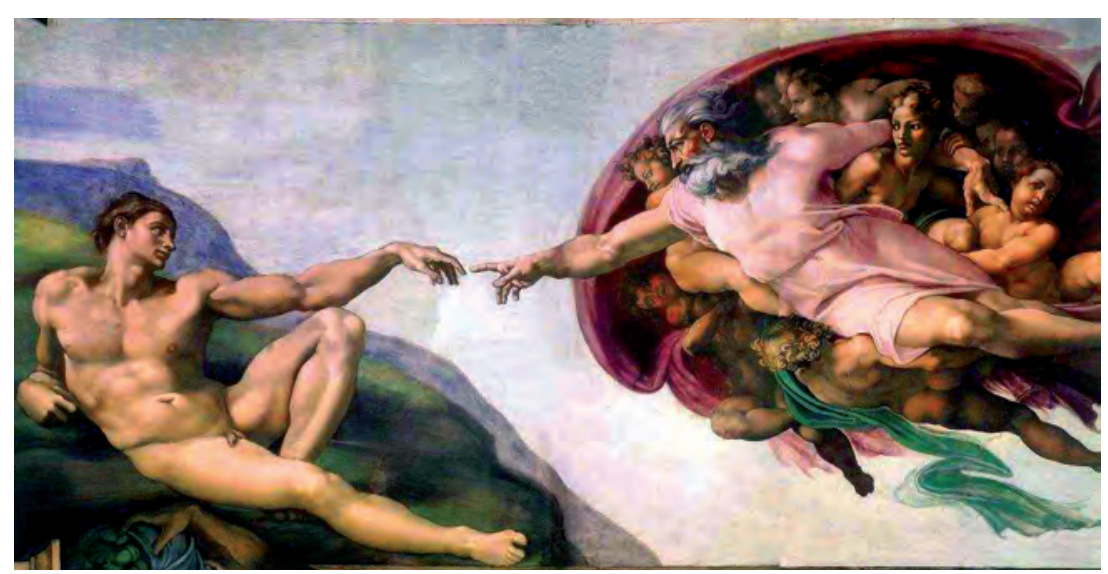

Fig. 17. Miguel Ángel, La creación de Adán, bóveda de la Capilla Sixtina. Roma 
En los inicios del siglo xvi, Miguel Ángel había pintado en la bóveda de la Capilla Sixtina a Dios concediéndole la vida a Adán por medio del toque sagrado [Fig. 17]. Durante los tres siglos siguientes e incluso en época ya postrevolucionaria los propagandistas áulicos rivalizaron en Europa por reivindicar para sus reyes un poder casi tan sobrecogedor como este. 